\title{
1-Amino-1,1-bisphosphonates. Fundamental syntheses and new developments
}

\author{
Vadim D. Romanenko and Valery P. Kukhar* \\ Institute of Bioorganic Chemistry and Petrochemistry, National Academy of Sciences, \\ Murmanska 1, Kyiv 94, 02660, Ukraine \\ E-mail:kukhar@bpci.kiev.ua
}

Dedicated to Prof. Pawel Kafarski to honor the achievements within his career

\begin{abstract}
1-Amino-1,1-bisphosphonates have become increasingly important in different fields of chemistry, medicine and agriculture. The combination of the unique physical, chemical and biological properties of methylenebisphosphonate and aminophosphonate fragments opens wide possibilities for the design of biologically active compounds including therapeutic agents to treat bone disorders related to calcium metabolism, immunomodulators, anti-infectives and plant growth regulators. The scope of this review is to summarize the existing strategies for the preparation of diversely functionalized 1-amino-1,1-bisphosphonates and to illustrate their utility as synthetic building blocks.
\end{abstract}

Keywords: Geminal bisphosphonic acids, bisphosphonates, 1-amino-1,1-bisphosphonates, bisphosphonate conjugates, pyrophosphates

\section{Table of Contents}

1. Introduction and short overview of biomedical applications

2. Synthesis from carboxylic acid amides

3. Synthesis from nitriles

4. Synthesis via three-component reaction involving an amine, triethyl ortoformate and diethyl phosphite

5. Synthesis from imines and related compounds

6. Block-building syntheses

7. Miscellaneous methods

8. Conclusions

9. References 


\section{Introduction and short overview of biomedical applications}

Aminophosphonic acids are amino carboxylic acid mimetics in which the carboxylic group is substituted by phosphonic acid residue $\mathrm{P}(\mathrm{O})(\mathrm{OH})_{2} .{ }^{1}$ On the other hand, geminal aminobisphosphonates, which are characterized by a $\mathrm{P}-\mathrm{C}(\mathrm{N})-\mathrm{P}$ backbone, besides that they are structural analogs of $\alpha$-aminophosphonic acids, may also be considered as carbon analogs of endogenous pyrophosphate $\left(\mathrm{PP}_{\mathrm{i}}\right)$ which is a regulator of calcium metabolism in living systems. Historically, aminophosphonic acids were first mentioned in the literature in the early 1940s in patents describing the synthesis of aminomethanephosphonic acid, $\mathrm{H}_{2} \mathrm{NCH}_{2} \mathrm{PO}_{3} \mathrm{H}_{2}{ }^{2,3}$ The first reports on 1-amino-1,1-bisphosphonic acids came a decade later. ${ }^{4}$ At the present time we know that aminomethylenebisphosphonates (AMBPs), $\mathrm{R}^{2} \mathrm{R}^{3} \mathrm{NC}(\mathrm{A})\left(\mathrm{PO}_{3} \mathrm{R}_{2}{ }_{2}\right)_{2}$, where $\mathrm{R}^{1}=\mathrm{H}, \mathrm{Alk} ; \mathrm{R}^{2}$, $\mathrm{R}^{3}=\mathrm{H}$, alkyl, aryl or heterocyclic group, and $\mathrm{A}=$ any substituent, have a broad spectrum of practical application. Along with 1-hydroxy-1,1-bisphosphonates, AMBPs are in clinical use as drugs to treat diseases associated with excessive osteoclast-mediated bone resorption such as osteoporosis, hypercalcemia, and Paget's disease ${ }^{5-8}$ plus they display antiparasitic ${ }^{9-15}$ antibacterial, ${ }^{16,17}$ and herbicidal ${ }^{18,19}$ activities. A number of AMBPs are also identified as potent low nanomolar inhibitors of the enzyme farnesyl pyrophosphate synthase (FPPS), a key regulatory enzyme in the mevalonate pathway. ${ }^{20-22}$ In addition to their activity against FPPS, some AMBPs also inhibit other biosynthesis pathway enzymes, such as squalene synthase ${ }^{23} \delta^{\prime}-$ pyrroline-5-carboxylate reductase, ${ }^{24} 1$-deoxyxylulose-5-phosphate reductoisomerase, ${ }^{25}$ and $T$. cruzi hexokinase (TcHK). ${ }^{26}$ AMBPs are also of interest in the context of cancer therapy since they stimulate human $\gamma \delta \mathrm{T}$ cells containing the $\mathrm{V} \gamma 2 \mathrm{~V} \delta 2 \mathrm{~T}$ cell receptor to proliferate and release large amounts of TNF $\alpha$ and IFN $\gamma$, leading to potential uses in immunotherapy. ${ }^{27}$ Moreover, the high affinity of bisphosphonates for mineralized tissues has led to application of these compounds as radiodiagnostic tools and bone-targeting moieties for drug and protein delivery with or without a polymeric platform. ${ }^{28}$ Selected examples of AMBPs used as therapeutic agents, herbicides, radiodiagnostic tools and metal-chelating ligands are shown in Chart 1. Thus, cycloheptylaminomethylene-1,1-bisphosphonate $\mathbf{1}$ is a representative of the latest generation of antiosteoporotic drugs and commercialized as Incadronate. ${ }^{6,29,30} \quad \mathrm{~N}$-Pyridyl-substituted aminomethylenebisphosphonic acids such as $\mathbf{2}$, developed in Japan, constitute new class of promising herbicides. ${ }^{18,19}$ Compound $\mathbf{2}$ is also potent FPPS inhibitor ${ }^{12}$ and both $\mathbf{2}$ and $\mathbf{3}$ are efficient inhibitors of bone resorption ${ }^{21,31}$. 1-Amino-1,1-bisphosphonates $\mathbf{4}$ and $\mathbf{5}$ are potent inhibitors of enzymatic activity of Trypanosoma cruzi, the causative agent of Chagas' disease. $^{10,26}$ In addition, bisphosphonate $\mathbf{4}$ turned out to be the potent inhibitor of acid sphingomyelinase (aSMase), an important drug target for a variety of diseases. ${ }^{32}$ Bisphosphonate $\mathbf{6}$ is a potent inhibitor of the methylerithritolphosphate (MEP) pathway enzyme deoxyxylulose-5-phosphate reductoisomerase which is used in the protozoan parasite Plasmodium falciparum, a causative agent of malaria. ${ }^{11,25}$ Biphenyl aminomethylenebisphosphonate 7 represents useful new lead for the development of antiamebic drugs. $^{11}$ 1-Amino-1,1-bisphosphonates such as $\mathbf{8}$ are of interest in the context of inhibitory 
activity on squalene synthetase, which plays an important role in the pathway of cholesterol biosynthesis. $^{33}$ Lanthanide(III) complexes of macrocyclic DOTA-like ligand 9 (BPAMD) containing a monoamide bis(phosphonic acid) bone-seeking group have great potential for applications in magnetic resonance imaging, radiodiagnosis and radiotherapy. ${ }^{34}$ Dipodal and tripodal ligands such as $\mathbf{1 0}$ are particularly interesting for uranyl sequestration. ${ }^{35}$ Aminomethylenebisphosphonates $\mathbf{1 1}$ have been involved in the conformational study of pyrrolinoxyl radicals and they also work as spin trapping agents relevant to biology. ${ }^{36-39}$

The structural origins of the biological activity of AMBPs are attributed to a favorable combination of acidic phosphonyl groups with a basic amino group attached to a common carbon. A consequence of this is that they may contain positively charged protonated nitrogen atom which decreases the net ligand charge when compared with non-nitrogen-containing bisphosphonate analogs. A close position of the nitrogen atom with respect of the bisphosphonate backbone results in an increase of the acidity of the phosphonate groups, thus allowing an efficient chelating of metal ions already at low $\mathrm{pH}$ values. ${ }^{40,41}$ In addition, the role of $\mathrm{PO}_{3} \mathrm{H}_{2}$ and $\mathrm{R}^{1} \mathrm{R}^{2} \mathrm{~N}$ groups attached to a prochiral carbon probably consists in that they provide specific orientation of the molecule on the surface of a biological object via hydrogen bond formation. Pharmacophores, such as substituents $A$ and $\mathrm{R}^{2}, \mathrm{R}^{3}$, may impart some physiologic activity to the molecule. Therefore, purposeful synthesis of functionalized aminobisphosphonate derivatives is of paramount importance in the search for compounds with a desirable biomedical profile.

As a result of the exceptionally interesting biological properties of bisphosphates, numerous books and reviews have been published that summarize biomedical ${ }^{5,42-49}$ and synthetic aspects $^{47,50-56}$ of the chemistry of bisphosphonates. However, the chemistry AMBPs has never been reviewed systematically. In this account we highlight some fundamentals concerning synthesis of AMBPs, together with most significant achievements that have appeared in literature during the last 10 years. Literature coverage for the review extends up to July 2011.

1-Aminomethylene-1,1-bisphosphonates (AMBPs) can be prepared in a number of different ways depending on the nature of organic moieties. ${ }^{1,9,11,47,50,51}$ The most common methods are (a) synthesis from carboxylic acid amides, (b) synthesis from nitriles, (c) synthesis via threecomponent reaction involving an amine, triethyl orthoformate and diethyl phosphite, (d) synthesis from imines and related compounds, and (e) block-building syntheses. All these methods are treated in detail in the next sections. 


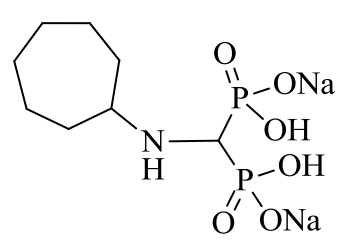

1

Incadronate

(YM-175, Yamanouchi Co.)<smiles>CCCCCC(N)(P(=O)(O)O)P(=O)(O)O</smiles>

4<smiles>O=P(O)(O)C(Nc1nccc2ccccc12)P(=O)(O)O</smiles>

6

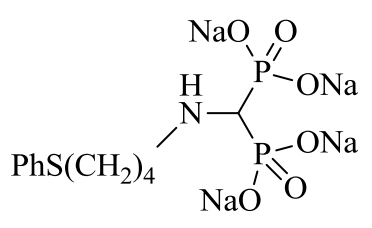

8<smiles>O=P(O)(O)C(Nc1ccc(Oc2cccc(Oc3ccc(NC(P(=O)(O)O)P(=O)(O)O)cc3)c2)cc1)P(=O)(O)O</smiles>

10<smiles>[R]c1cnc(NC(P(=O)(O)O)P(=O)(O)O)c([R])c1</smiles>

$2 \mathrm{R}^{1}=\mathrm{R}^{2}=\mathrm{H}$

(NE 58025, Procter and Gamble Co.));

$$
3 \mathrm{R}^{1}=\mathrm{Me}, \mathrm{R}^{2}=\mathrm{H}
$$

(NE 97220, Procter and Gamble Co.)<smiles>CCn1c2ccccc2c2cc(NC(P(=O)(O)O)P(=O)(O)O)ccc21</smiles>

5

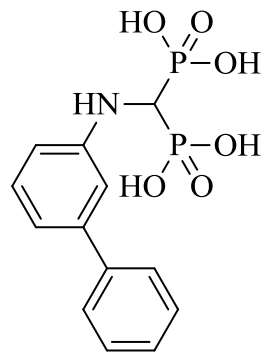

7

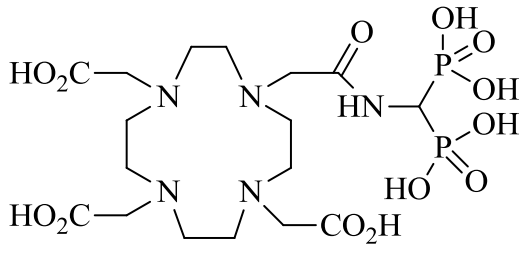

9

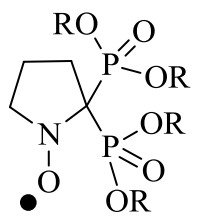

$\mathrm{R}=\mathrm{Et}, \mathrm{Pr}^{\mathrm{i}}, \mathrm{Na}$

11

Structure block 1. Examples of 1-aminomethylene-1,1-bisphosphonates exhibiting important biological properties 


\section{Synthesis from carboxylic acid amides}

In 1972 Plöger et al. ${ }^{57}$ have described the direct phosphonation of formamide with phosphorous acid or phosphorus trichloride in the presence of water. Mechanism of the reaction has not been studied, however such transformation must inevitably involve a number of stages, such as the formation of the intermediate 12, its dehydration and addition of another $\mathrm{H}_{3} \mathrm{PO}_{3}$ molecule (Scheme 1). In the optimized procedure, formamide are added to a mixture of $\mathrm{H}_{3} \mathrm{PO}_{3}$ and $\mathrm{PCl}_{3}$ and then heated for $7 \mathrm{~h}$ at $70-75{ }^{\circ} \mathrm{C}$. After hydrolysis the compound $\mathbf{1 3}$ is isolated as the sole product in $30-44 \%$ yield. ${ }^{58,59}$ The formation of iminobis(methylenebisphosphonic acid), $\mathrm{HN}\left[\mathrm{CH}\left(\mathrm{PO}_{3} \mathrm{H}_{2}\right)_{2}\right]_{2}$, as minor product was also detected. ${ }^{59}$ Using $N, N$-dialkylformamides in place of formamide, dialkylaminomethylene-1,1-bisphosphonic acids $\mathbf{1 4}$ were synthesized in a similar manner to $\mathbf{1 3}$ (Scheme 2). ${ }^{60}$
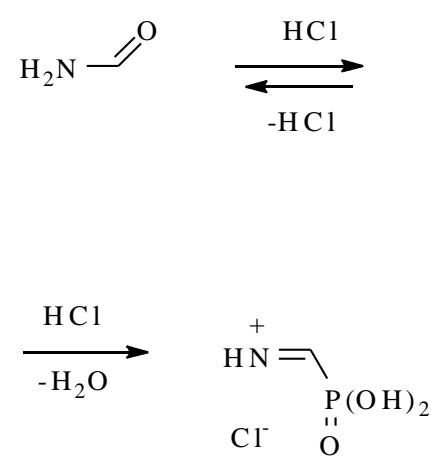
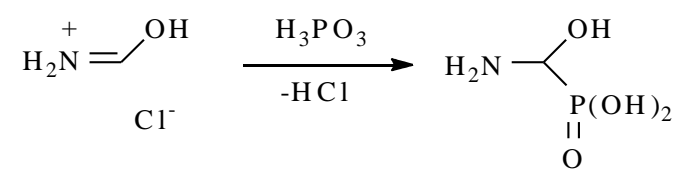

12

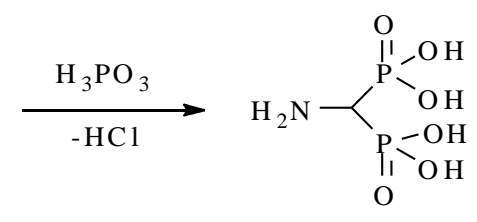

13

\section{Scheme 1}

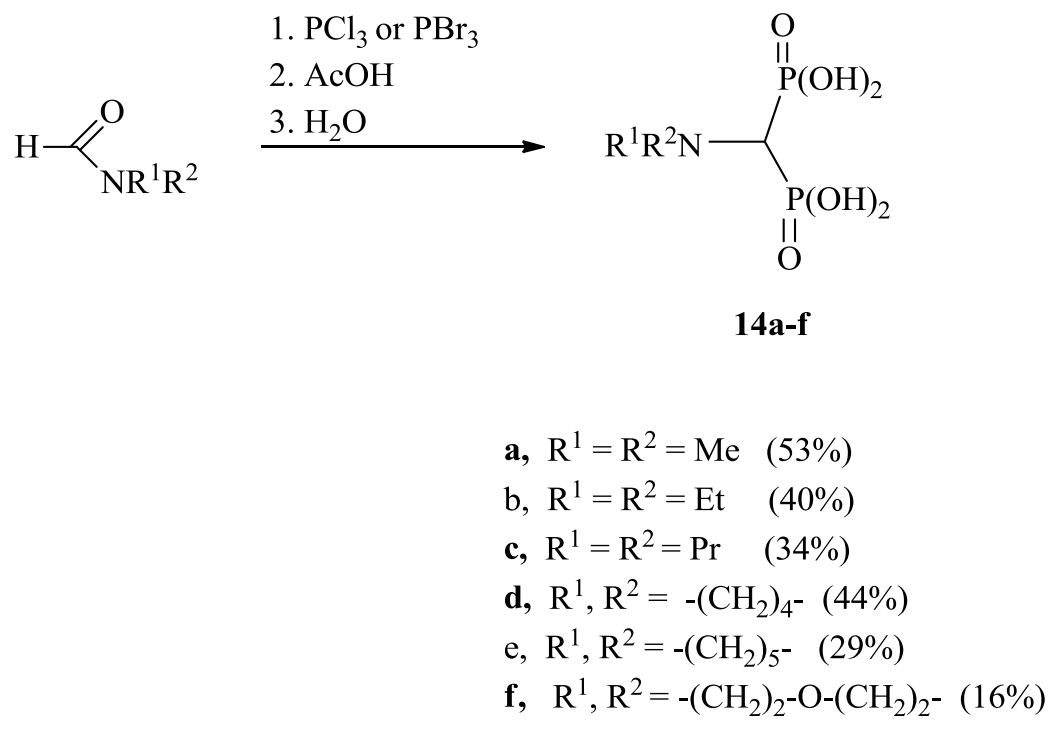

Scheme 2 
Chen and co-workers ${ }^{61}$ have developed a simple and convenient one-pot procedure for the synthesis of aminomethylene-1,1-bisphosphonic acids using primary and secondary amines as the starting materials. In this case amines are formylated by formic acid to give the intermediate formamides which directly react with $\mathrm{PCl}_{3} / \mathrm{H}_{2} \mathrm{O}$ to afford the corresponding bisphosphonic acids 14 (Scheme 3).

Primary, secondary and tertiary amides of alkanecarboxylic acids are also suitable substrates for bisphosphonation. ${ }^{10,32,62}$ Thus, when $O$-benzyloxyacetamide $15, \mathrm{H}_{3} \mathrm{PO}_{3}$ and $\mathrm{PCl}_{3}$ were heated together for 1 hour at $70{ }^{\circ} \mathrm{C}$, the protected 1-amino-2-hydroxyethylene-1,1-bisphosphonic acid 16 has been prepared in $39 \%$ yield. Catalytic hydrogenolysis of $\mathbf{1 6}$ gave the corresponding 1-amino2-hydroxyethylidene-1,1-bisphosphonate 17 (Scheme 4). ${ }^{63}$

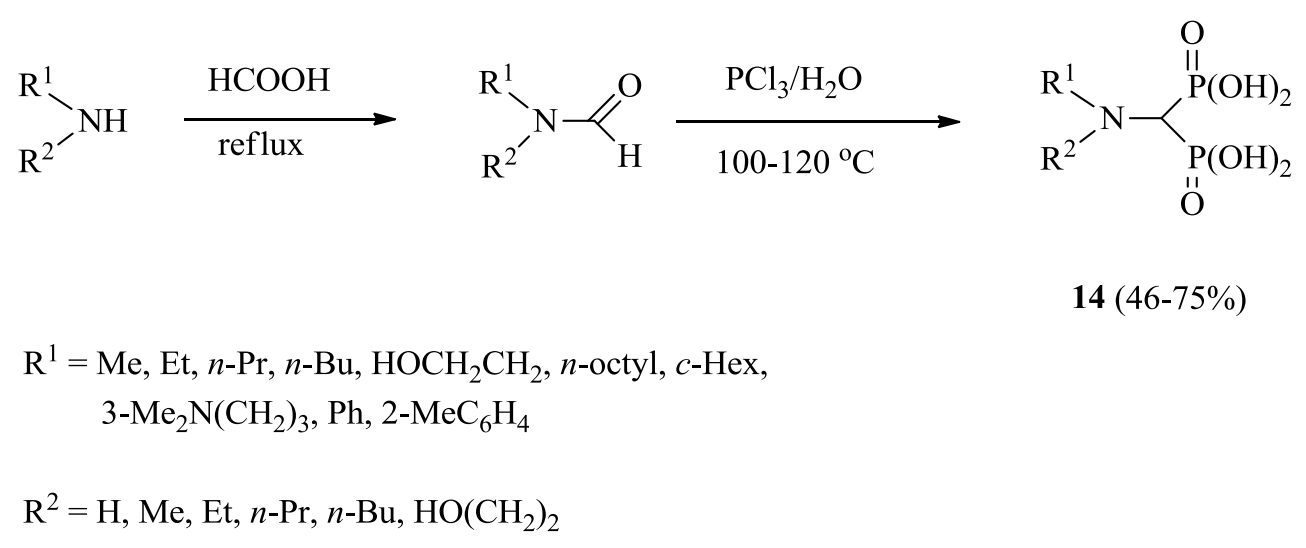

\section{Scheme 3}

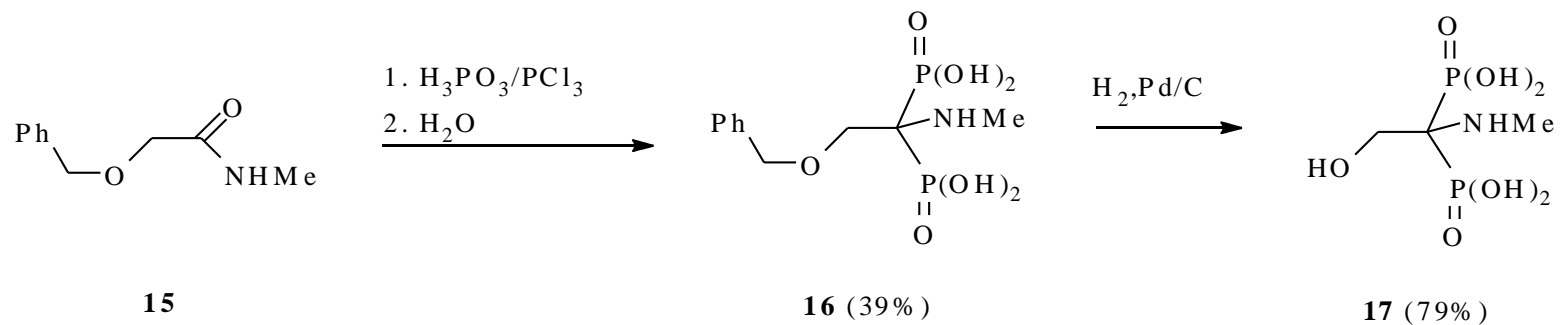

\section{Scheme 4}

Worms and Blum reported the formation of AMBPs from diamides $18{ }^{64}$ The outcome of reaction depends on the structure of a diamide. With $n>3$, a mixture of bis- and tetraphosphonic acids 19 and $\mathbf{2 0}$ is obtained. However, with $\mathrm{n}=2$ or 3 , only cyclic bisphosphonic acids $\mathbf{2 1}$ are formed (Scheme 5).

Depending on reaction conditions, the phosphonation of $N$-alkylacetamides with $\mathrm{H}_{3} \mathrm{PO}_{3} / \mathrm{PCl}_{3}$ in $\mathrm{B} \cdot \mathrm{HCl}$ media $\left(\mathrm{B}=\mathrm{Py}, \mathrm{Bu}_{3} \mathrm{~N}\right)$ gives either bisphosphonic acids $\mathbf{2 2}$ or dianhydrides 23 . The latter convert into monocyclic forms $\mathbf{2 4}$ under mild acetic hydrolysis (Scheme 6). ${ }^{62}$ Unexpected 
formation of dianhydrides $\mathbf{2 3}$ was attributed to participation in the reaction of imines $\mathrm{MeC}\left(\mathrm{POX}_{2}\right)=\mathrm{NR}\left(\mathrm{POX}_{2}\right.$ means anhydryzed $\left.\mathrm{PO}_{3} \mathrm{H}_{2}\right)$. This imine may form due to both the phosphonylation of acetamide and the reverse dephosphonylation of bisphosphonic acids 22 . Tautomerization gives the $\mathrm{C}$-nucleophilic enamine $\mathrm{CH}_{2}=\mathrm{C}\left(\mathrm{POX}_{2}\right)-\mathrm{NHR}$ whereas protonation affords the C-electrophile. Their interaction leads to the formation of a new $\mathrm{C}-\mathrm{C}$ bond and yields dianhydrides 23.<smiles>[R]NC(=O)C(C)C(=O)N[R]</smiles>
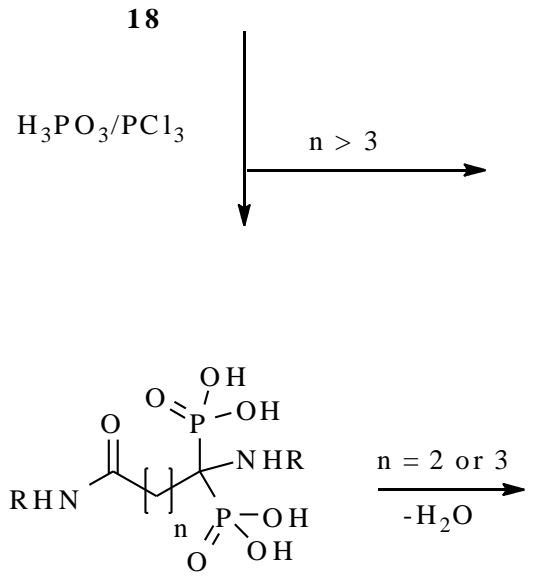

19

$\mathrm{R}=\mathrm{H}, \mathrm{Me}$

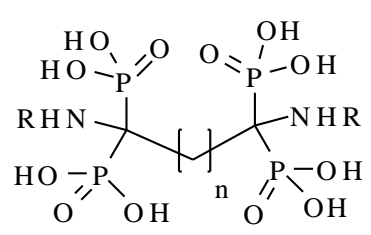

20
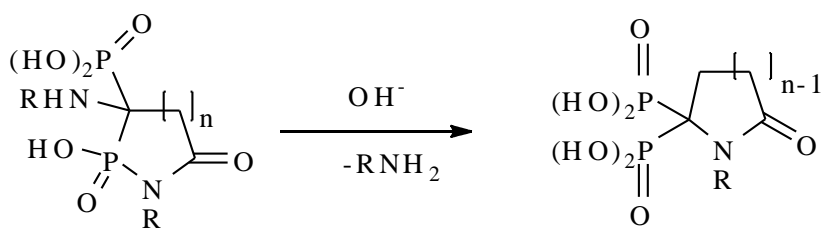

21

\section{Scheme 5}

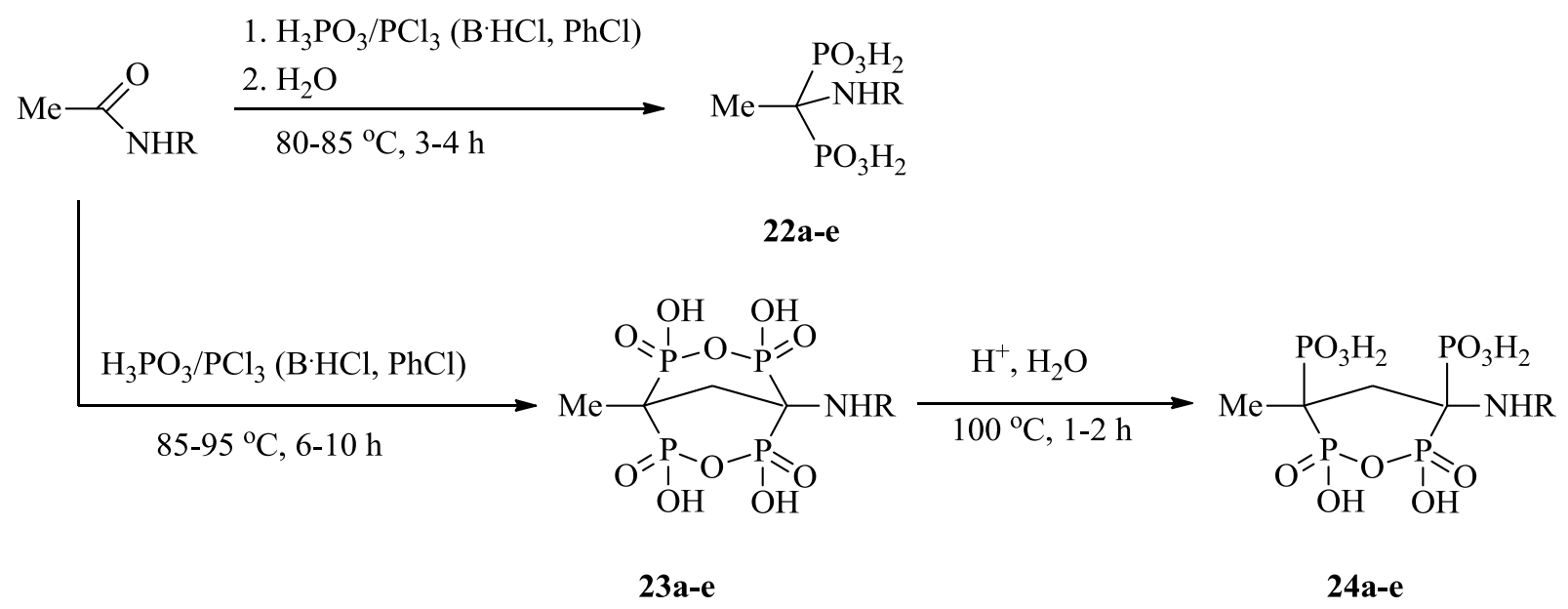

$\mathrm{R}=\mathrm{Me}(\mathrm{a}), \mathrm{Bu}(\mathrm{b})$, cyclo- $\mathrm{C}_{6} \mathrm{H}_{11}$ (c), $\mathrm{C}_{12} \mathrm{H}_{25}$ (d), $\mathrm{PhCH}_{2}$ (e)

$\mathrm{B}=\mathrm{Py}$ or $\mathrm{Bu}_{3} \mathrm{~N}$

\section{Scheme 6}


The amides $\mathrm{R}^{1} \mathrm{CONHR}{ }^{2}\left(\mathrm{R}^{1} \neq \mathrm{H}, \mathrm{Me}\right)$ react with $\mathrm{H}_{3} \mathrm{PO}_{3} / \mathrm{PCl}_{3}$ in $\mathrm{B} \cdot \mathrm{HHlg}(\mathrm{Hlg}=\mathrm{Cl}, \mathrm{Br})$ to give both $N$-alkyl- (or $N$-unsubstituted) 1-aminoalkylidene-1,1-bisphosphonic acids 25 and their cyclic dimeric anhydrides 26 (Scheme 7). ${ }^{62}$

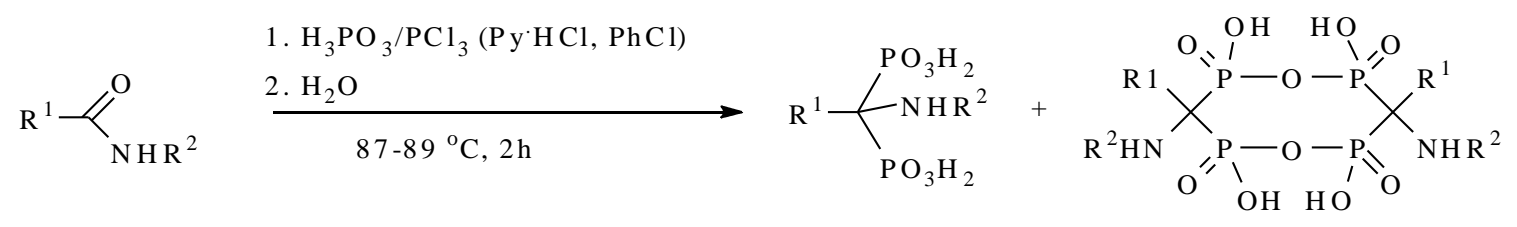

$$
\begin{aligned}
& \mathrm{R}^{1}=\mathrm{Et}, \mathrm{Bu}, \mathrm{C}_{7} \mathrm{H}_{15}, \mathrm{C}_{11} \mathrm{H}_{23}, 4-\mathrm{MeC}_{6} \mathrm{H}_{4} \\
& \mathrm{R}^{2}=\mathrm{Me}, \mathrm{Bu}, \mathrm{C}_{6} \mathrm{H}_{13}, \mathrm{C}_{7} \mathrm{H} 15, \mathrm{C}_{8} \mathrm{H}_{17}, \mathrm{C}_{11} \mathrm{H}_{23}
\end{aligned}
$$

\section{Scheme 7}

Efficient phosphonylation of amides can also be achieved via Vilsmeier reagents $\left(\mathrm{R}^{1} \mathrm{CONR}^{2} \mathrm{R}^{3} / \mathrm{POCl}_{3}\right)$. It should be noted that early findings by Gross ${ }^{65}$ and Degenhardt ${ }^{66}$ demonstrated that dimethylchloroformiminium chloride, $\left[\mathrm{Me}_{2} \mathrm{~N}=\mathrm{CHCl}\right]^{+} \mathrm{Cl}^{-}$(prepared from DMF and oxalyl chloride), could react with $\mathrm{P}(\mathrm{OEt})_{3}$ to give $\mathrm{Me}_{2} \mathrm{~N}-\mathrm{CH}\left(\mathrm{PO}_{3} \mathrm{Et}\right)_{2}$. More recently, it was shown that treatment of the Vilsmeier reagents with 2 equivalents of trialkyl- or dialkyl phosphite provides simple and efficient route to AMBPs. ${ }^{36,37,67,68}$ The reactions proceed under very mild conditions $\left(20{ }^{\circ} \mathrm{C}, 8-12\right.$ hours $)$ and presumably involve the intermediate formation of phosphoryliminium chlorides, their transformation into corresponding phosphonyliminium chlorides and subsequent addition of the next dialkyl phosphite molecule (Scheme 8). Yields of products usually vary from 45 to $65 \%$. Using sterically crowded amides such as MeC(O)NHR $\left(\mathrm{R}=t\right.$ - $\mathrm{Bu}, \sec -\mathrm{Bu}$ ) leads to bisphosphonate products in low yield, typically $20-30 \% .^{38}$

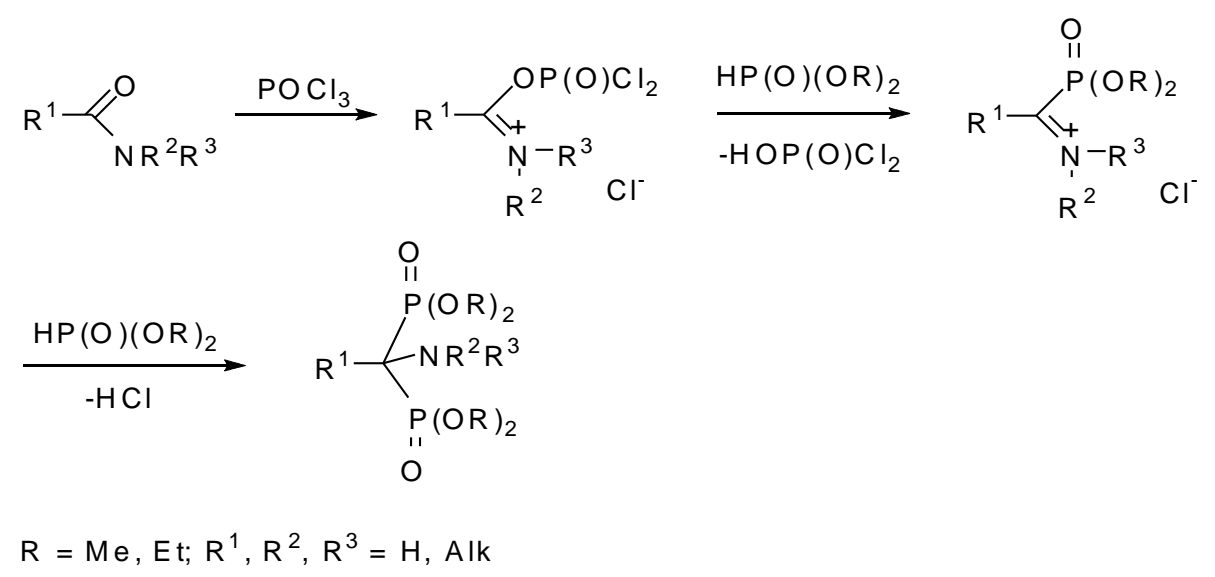

\section{Scheme 8}


Surprisingly, primary amides $\mathrm{RC}(\mathrm{O}) \mathrm{NH}_{2}\left(\mathrm{R}=\mathrm{Me}, \mathrm{PhCH}_{2}\right)$ did not react with $\mathrm{POCl}_{3}$ in the presence of $\mathrm{P}(\mathrm{OEt})_{3} \cdot{ }^{36}$ On the other hand, when the Vilsmeier reagent $\mathrm{PhCH}_{2} \mathrm{C}(\mathrm{O}) \mathrm{NMe}_{2} / \mathrm{POCl}_{3}$ was treated with diethyl phosphite in a molar ratio of 1:2, the bisphosphonate 27 was formed in $37 \%$ yield. ${ }^{68}$ The addition into the reaction mixture of triethylamine initiates a different reaction pattern and gives rise to $E$-vinylphosphonates 28 (Scheme 9). ${ }^{69}$ Should also be noted that hydridophosphorane $\mathbf{2 9}$ reacts with the Vilsmeier reagents similar to dialkyl phosphites forming methylenebisphosphoranes $\mathbf{3 0}$ (Scheme 10). ${ }^{67,69,70}$

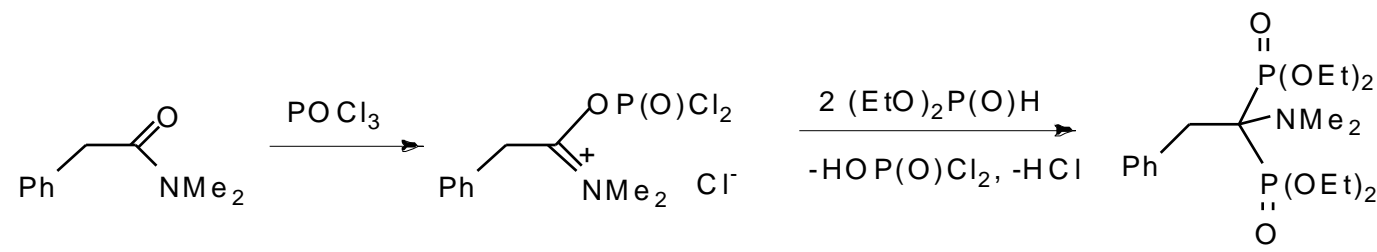

27

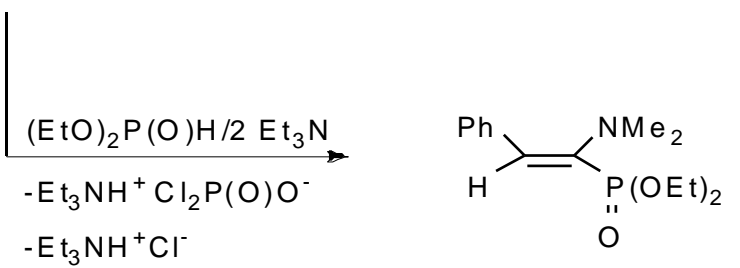

28

\section{Scheme 9}

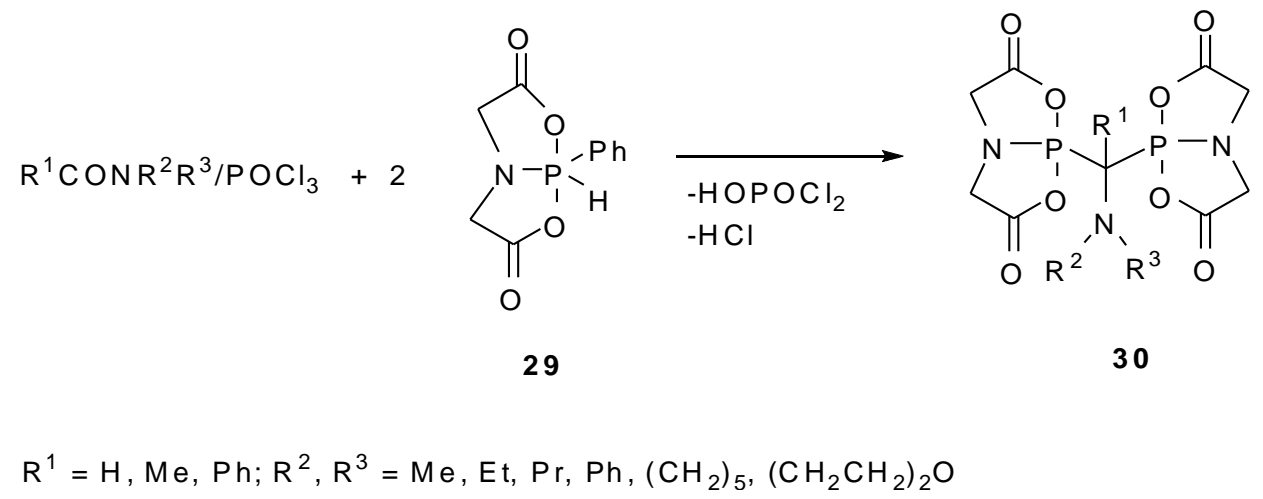

\section{Scheme 10}

Tordo and co-workers ${ }^{39}$ have succeeded in preparing alicyclic analogues of AMBPs in reasonable yield by the reaction of pyrrolidine-2-one and triethyl phosphite with $\mathrm{POCl}_{3}(\mathrm{Scheme}$ 11). The oxidation of $\mathbf{3 1}$ with dimethyldioxirane, prepared in situ from oxone and acetone, led to the bisphosphonylated nitrone 32, which can be used in spin trap experiments. The same authors 
then extended this method to other trialkyl phosphites $\mathrm{P}(\mathrm{OR})_{3}(\mathrm{R}=i$-Pr, $\mathrm{Bu})$ and lactams. ${ }^{37} \mathrm{By}$ applying the method to 2-azitidinone and 2-piperidone, bisphosphonates $\mathbf{3 3}$ and $\mathbf{3 4}$ have been obtained in $28 \%$ and $19 \%$ yields, correspondingly. Bisphosphonylation of $N$-methylpyrrolidine2-one afforded the expected bisphosphonate in $17 \%$ yield. However, attempts to prepare the tetraphosphonylated product $\mathbf{3 5}$ from succinimide failed. ${ }^{36}$ A multinuclear magnetic resonance study $\left({ }^{1} \mathrm{H},{ }^{13} \mathrm{C},{ }^{31} \mathrm{P},{ }^{15} \mathrm{~N}\right)$ was performed on a series of new cyclic bisphosphonates. ${ }^{71}$

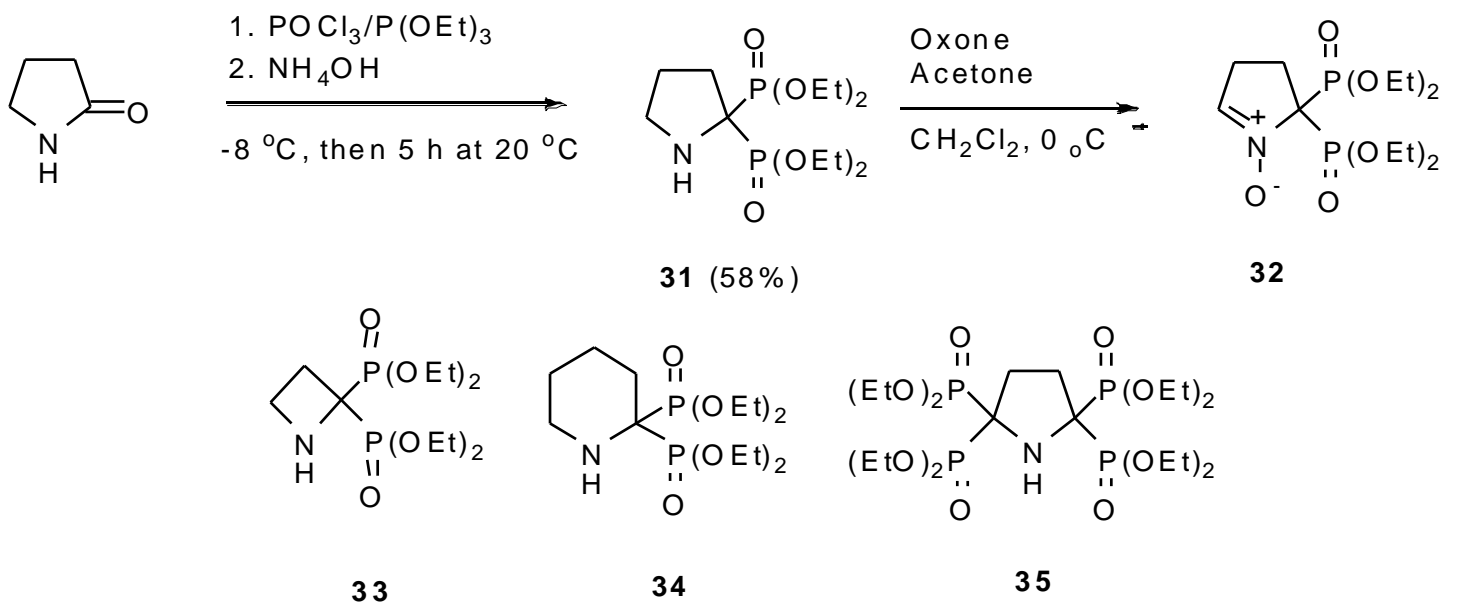

\section{Scheme 11}

\section{Synthesis from nitriles}

By analogy with the synthesis of 1-amino-1,1-bisphosphonates from amides and phosphonating agents, aminobisphosphonic acids may be obtained from nitriles and phosphorous acid $\left(\mathrm{H}_{3} \mathrm{PO}_{3}\right)$ or phosphorus trihalide $\left(\mathrm{PCl}_{3}, \mathrm{PBr}_{3}\right)$ in the presence of water. Some preparative examples of the syntheses are given in Methods of Preparation of Chemicals and Drugs. ${ }^{72}$ In particular, 1aminoethylidene-1,1-bisphosphonic acid, $\mathrm{H}_{2} \mathrm{NC}(\mathrm{Me})\left(\mathrm{PO}_{3} \mathrm{H}\right)_{2}$, is available from acetonitrile and $\mathrm{H}_{3} \mathrm{PO}_{3}{ }^{73}, \mathrm{PBr}_{3} / \mathrm{H}_{3} \mathrm{PO}_{3}{ }^{72}$ or $\mathrm{PCl}_{3} / \mathrm{H}_{2} \mathrm{O}^{74}$ in the presence of large excess of hydrogen chloride. It is assumed that hydrogen chloride activates acetonitrile and intermediately formed imines in the reaction with phosphorous acid (Scheme 12). ${ }^{75}$ Phosphonylation of acetonitrile has been carried out also with diethyl phosphite in the presence of $\mathrm{PBr}_{3}{ }^{62}$ or hydrogen chloride ${ }^{76}$. In the last case, depending on the ratio of reagents and reaction conditions mono-, di- and tetraethyl esters of the corresponding bisphosphonic acid have been obtained. 


$$
\begin{aligned}
& \mathrm{Me}-\mathrm{CN} \stackrel{\mathrm{HCl}}{\longrightarrow} \mathrm{Me}-\mathrm{C} \equiv \mathrm{NH}^{+} \mathrm{Cl}^{-} \stackrel{\mathrm{H}_{3} \mathrm{PO}_{3}, \mathrm{HCl}}{\longrightarrow}\left[\begin{array}{c}
\stackrel{+}{\mathrm{P}}(\mathrm{OH})_{3} \\
\mathrm{Me}^{-} \stackrel{\mathrm{NH}}{\mathrm{NH}^{-}}
\end{array}\right] \underset{-\mathrm{HCl}}{\longrightarrow}
\end{aligned}
$$

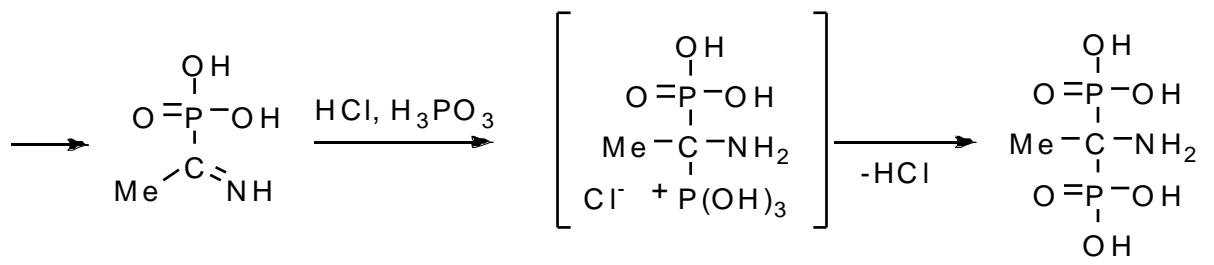

\section{Scheme 12}

1-Aminoalkylidene-1,1-bisphosphonic acids 36-39 derived from fatty acids are most conveniently prepared by reacting the corresponding nitriles with $\mathrm{H}_{3} \mathrm{PO}_{3}$ or $\mathrm{PCl}_{3} / \mathrm{H}_{3} \mathrm{PO}_{3} / \mathrm{PhSO}_{3} \mathrm{H}$ system (Scheme 13). ${ }^{10}$ Similarly, benzyl cyanide easily reacts with $\mathrm{H}_{3} \mathrm{PO}_{3}$ to give the bisphosphonic acid $\mathrm{PhCH}_{2} \mathrm{C}\left(\mathrm{NH}_{2}\right)\left(\mathrm{PO}_{3} \mathrm{H}_{2}\right)_{2}$. Also 4-nitrophenylacetonitrile has been successfully transformed to the corresponding bisphosphonic acid, this time by the reaction with $\mathrm{H}_{3} \mathrm{PO}_{3} / \mathrm{PCl}_{3}{ }^{77}$ In contrast, under the standard reaction conditions benzonitrile exhibits very low reactivity toward phosphorous acid even in the presence of a large excess of hydrogen chloride. However, heating of $\mathrm{PhCN}$ and $\mathrm{H}_{3} \mathrm{PO}_{3}$ in the presence of $\mathrm{AlCl}_{3}$ at $180{ }^{\circ} \mathrm{C}$ followed by hydrolysis leads to the formation of the 1-aminobenzylidene-1,1-bisphosphonic acid in $80-90 \%$ yield. $^{78}$

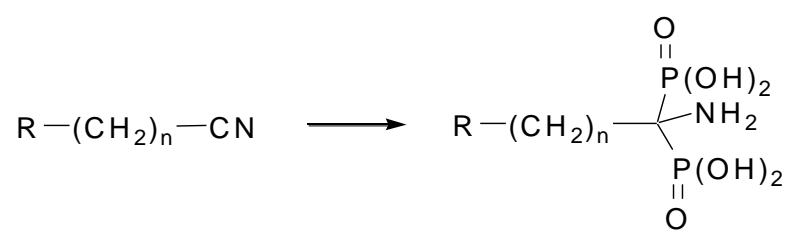

$$
\begin{aligned}
& 36, n=1(70 \%) \\
& 37, n=2(53 \%) \\
& 38, n=3(25 \%) \\
& 39, n=4(15 \%)
\end{aligned}
$$

\footnotetext{
Reagents and conditions: EtCN, $\mathrm{H}_{3} \mathrm{PO}_{3}, 135{ }^{\circ} \mathrm{C}$, $12 \mathrm{~h}$ for 36; (i) $\mathrm{PrCN}, \mathrm{H}_{3} \mathrm{PO}_{3}, \mathrm{PhSO}_{3} \mathrm{H}, 65{ }^{\circ} \mathrm{C}, 10$ min, (ii) $\mathrm{PCl}_{3}, 70{ }^{\circ} \mathrm{C}, 6 \mathrm{~h}$ for 37 ; (i) $\mathrm{BuCN}, \mathrm{H}_{3} \mathrm{PO}_{3}$, $\mathrm{PhSO}_{3} \mathrm{H}, 65{ }^{\circ} \mathrm{C}, 10 \mathrm{~min}$, (ii) $\mathrm{PCl}_{3}, 85^{\circ} \mathrm{C}, 16 \mathrm{~h}$ for 38; (i) $\mathrm{C}_{5} \mathrm{H}_{11} \mathrm{CN}, \mathrm{H}_{3} \mathrm{PO}_{3}, \mathrm{PhSO}_{3} \mathrm{H}, 70{ }^{\circ} \mathrm{C}, 10 \mathrm{~min}$, (ii) $\mathrm{PCl}_{3}, 90{ }^{\circ} \mathrm{C} 16 \mathrm{~h}$ for 39
}

\section{Scheme 13}


Dinitriles of malonic, succinic, glutaric, and adipic acids can also be used to give the diaminotetraphosphonic acids of the general formula $\mathbf{4 0}$ (Scheme 14). ${ }^{77}$

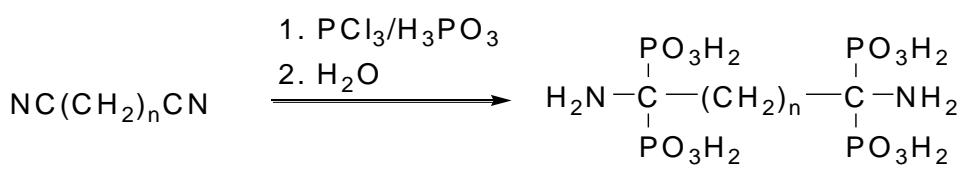

40, $\mathrm{n}=1-4$

\section{Scheme 14}

The harsh reaction conditions restrict application of the method for the synthesis of polyfunctional bisphosphonates. Nevertheless, some functionalized 1-aminoalkylidene-1,1bisphosphonates can be prepared from substituted nitriles. For example, benzimidazolylsubstituted bisphosphonic acid $\mathbf{4 1}$ has been synthesized by treatment of the $N$-(2cyanoethyl)benzimidazole with $\mathrm{PBr}_{3}$ and water in dioxane as solvent (Scheme 15). ${ }^{79}$
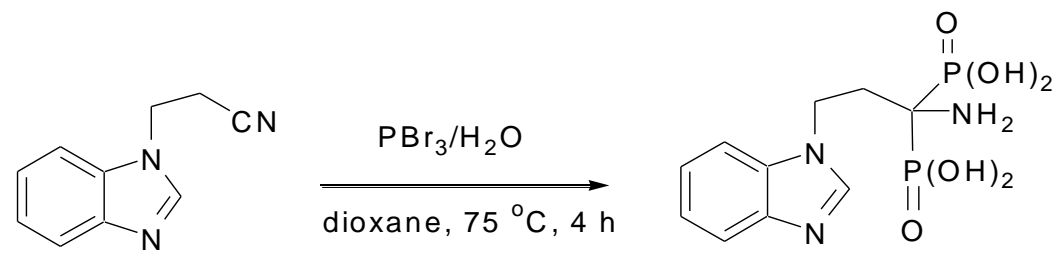

$41(65 \%)$

\section{Scheme 15}

A Russian research group reported the conversion of cyanoacetic acid into bisphosphonic acid 42 (23\%) upon treatment with $\mathrm{PBr}_{3}$ at $25{ }^{\circ} \mathrm{C}$ for $50 \mathrm{~h}$ followed by hydrolysis. In the standard reaction conditions $\left(\mathrm{H}_{3} \mathrm{PO}_{3}, 200{ }^{\circ} \mathrm{C}\right)$ only decarboxylated 1-aminoethylidene-1,1-bisphosphonic acid could be isolated. ${ }^{73}$ From cyanoacetamide and $\mathrm{PCl}_{3} / \mathrm{H}_{3} \mathrm{PO}_{3}$ the bisphosphonic acid 43 has been prepared in $36 \%$ yield. ${ }^{77}$ Reasonably good yield of the bisphosphonic acid 44 was obtained from 3-(dimethylamino)propionitrile while treating it with $\mathrm{PBr}_{3} / \mathrm{H}_{3} \mathrm{PO}_{4}$ mixture (Scheme 16). ${ }^{6}$

Blum has studied the reaction of 3-oxonitriles 45 with a mixture of $\mathrm{H}_{3} \mathrm{PO}_{3}$ and $\mathrm{PBr}_{3} .{ }^{80}$ Bisphosphonates $\mathbf{4 6}$ were obtained in modest yields and are valuable synthons for the synthesis of other types of bisphosphonic acids such as $\mathbf{4 7}$ and $\mathbf{4 8}$ (Scheme 17). 


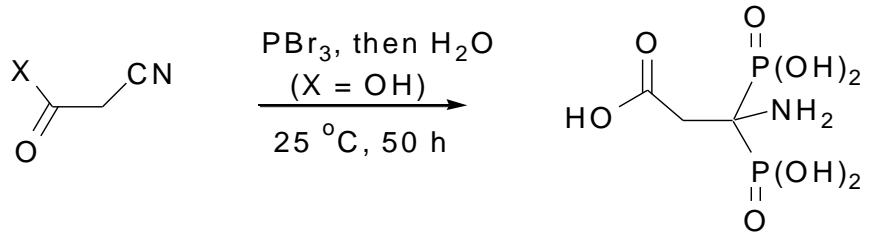

$42(23 \%)$
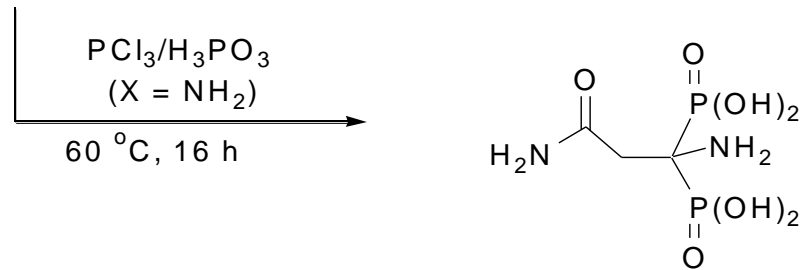

$43(36 \%)$

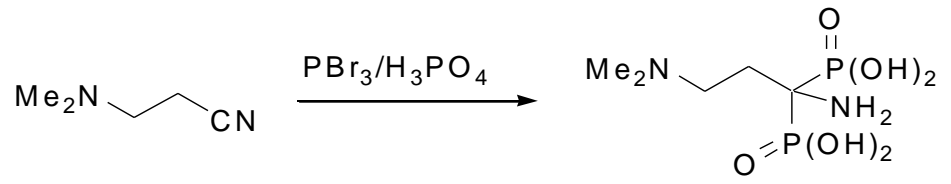

$44(56 \%)$

\section{Scheme 16}

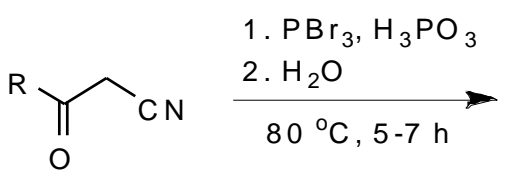

45

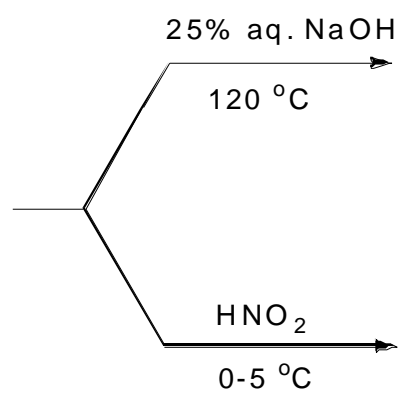

$R=E t_{2} \mathrm{MeC}(\mathrm{a}), \operatorname{PrMe}_{2} \mathrm{C}(\mathrm{b}), \mathrm{HexMe}_{2} \mathrm{C}$ (c)

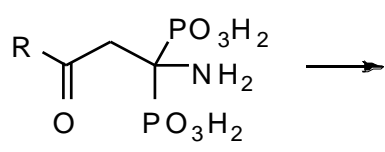

$46 a-c(66-35 \%)$

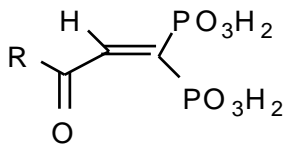

47 a-c $(65-75 \%)$<smiles>[2H]C(=O)CC(O)(P)P(O)O</smiles>

48 a,b (41-46\%)

Scheme 17 
Under standard reaction conditions $\left(\mathrm{PCl}_{3} / \mathrm{H}_{3} \mathrm{PO}_{3}\right.$ as phosphonylating agent, heating at $60{ }^{\circ} \mathrm{C}$ for 12-14 $\mathrm{h}$ followed by hydrolysis at $0{ }^{\circ} \mathrm{C}$ ) cyanoethyl derivatives of certain peptides, namely glycineglycine, glycylalanine, glycylleucine, and alanylmethionine, furnished the peptidederivatized 1-amino-1,1-bisphosphonic acids $\mathbf{4 9 - 5 2}$ (Scheme 18, Table 1). ${ }^{77}$

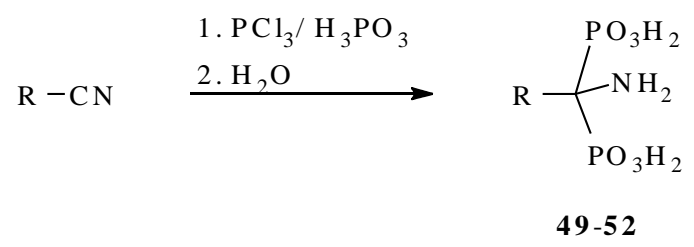

\section{Scheme 18}

Table 1. Peptide-derivatized 1-amino-1,1-bisphosphonic acids 49-52

Compound 59

\section{Synthesis via three-component reaction involving an amine, triethyl orthoformate and diethyl phosphite}

This route is based on the triethyl orthoformate promoted P-C-P bond formation reaction first reported by Suzuki ${ }^{81}$ and further extended by Maier ${ }^{82}$ and Ebetino et al. ${ }^{83}$ The standard procedure for the synthesis of $N$-pyridylaminomethylene bisphosphonic 53 and bisphosphinic 54 acids developed by these authors consists in heating a mixture of triethyl orthoformate, an aminopyridine and diethyl phosphite or ethyl hydrogen alkylphosphinate, $\mathrm{HP}(\mathrm{O})(\mathrm{OEt}) \mathrm{R}$, followed by aqueous hydrolysis (Scheme 19). It was later shown that a wide range of primary and secondary amines enter into this kind of reactions. ${ }^{29,84}$ An important variation, with the 
utilization of trialkyl phosphites ${ }^{85-87}$ was also reported. Moreover, the biological importance of 1aminomethylene-1,1-bisphosphonates has prompted the developments of improved methodologies including synthesis under solvent-free conditions, ${ }^{88}$ catalytic synthesis, ${ }^{89}$ and activation with microwave irradiation. ${ }^{88,90}$
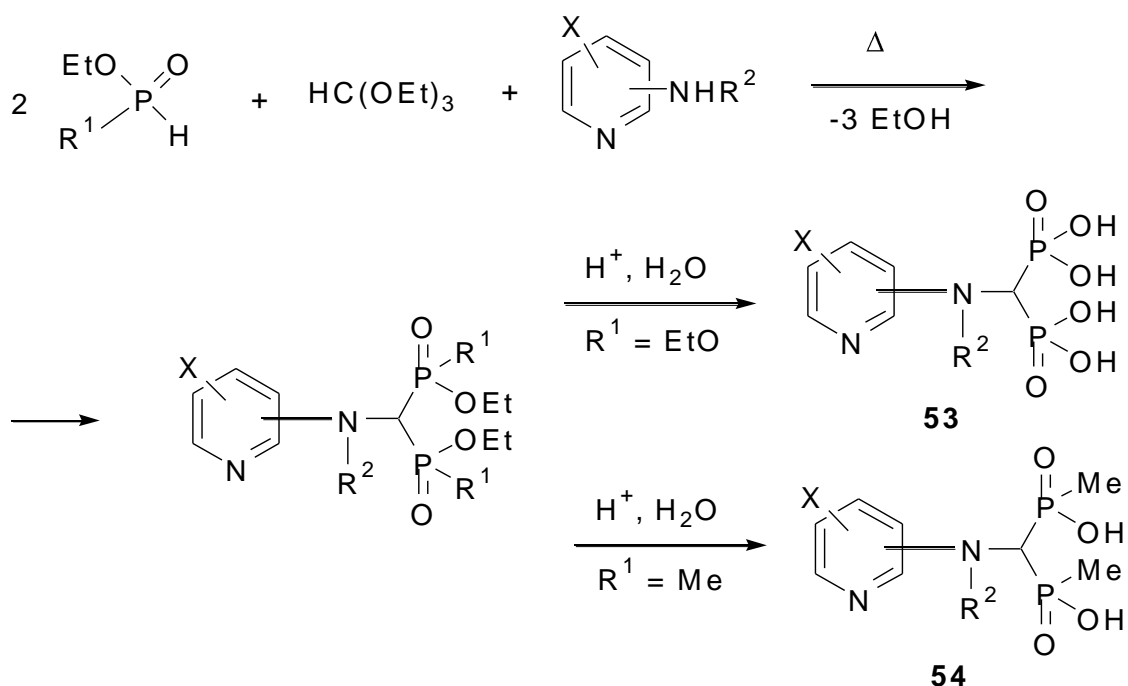

$$
\mathrm{R}^{1}=\mathrm{Me}, \mathrm{EtO} ; \mathrm{R}^{2}=\mathrm{H}, \mathrm{Alk}
$$

\section{Scheme 19}

The mechanism of three component condensation leading to AMBPs has been investigated by Kafarski and co-workers. ${ }^{91}$ On the basis of ${ }^{31} \mathrm{P}$ NMR technique and preparative experiments, they demonstrated that the reaction is quite complex and proceeds via a series of imine and aminophosphonate intermediates existing in kinetic and thermodynamic equilibrium (Scheme 20).

In spite of complex reaction pathway, the method appears to be fairly general and can be applied for the construction of various $N$-monosubstituted and $N, N$-disubstituted 1aminomethylenebisphosphonates bearing alkyl, cycloalkyl and aryl substituents at the nitrogen atom. $^{11,84,89}$ Of recent studies, should be mentioned synthesis of non-carrier-added (nca) ${ }^{131}$ Ilabeled bisphosphonic acid $\mathbf{5 7}$ by the reaction of the amine $\mathbf{5 5}$ with triethyl ortoformate and diethyl phosphite followed by iododesilylation (Scheme 21). ${ }^{92}$ Another recent example is threecomponent reaction between aminoadamantanes 58, triethyl ortoformate and diethyl phosphite which was used to obtain bisphosphonates 59. This conversion was carried out under microwave irradiation $\left(400 \mathrm{~W}, 150{ }^{\circ} \mathrm{C}\right)$. Disubstituted adamantane 60 was also prepared according this procedure (Scheme 22). ${ }^{88}$ 


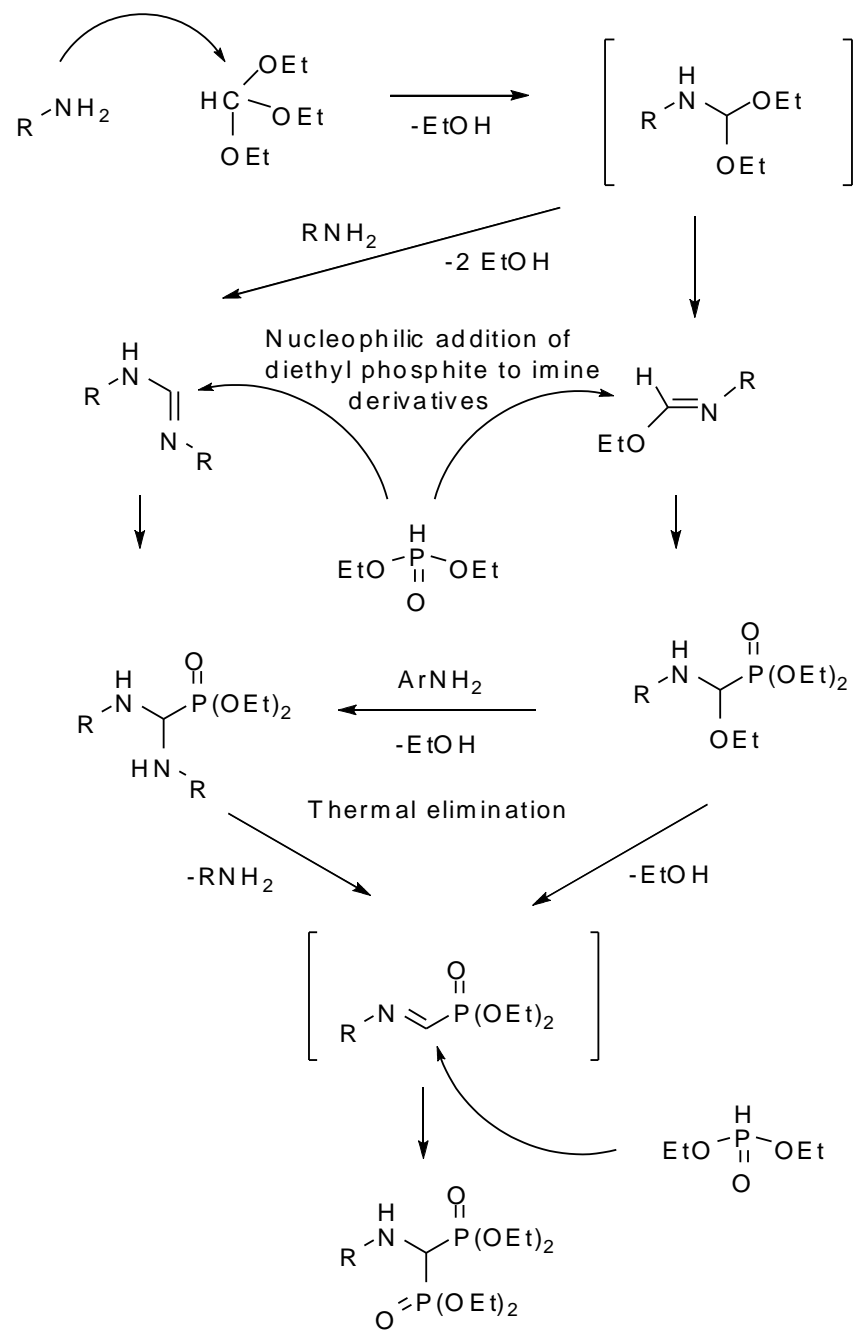

\section{Scheme 20}

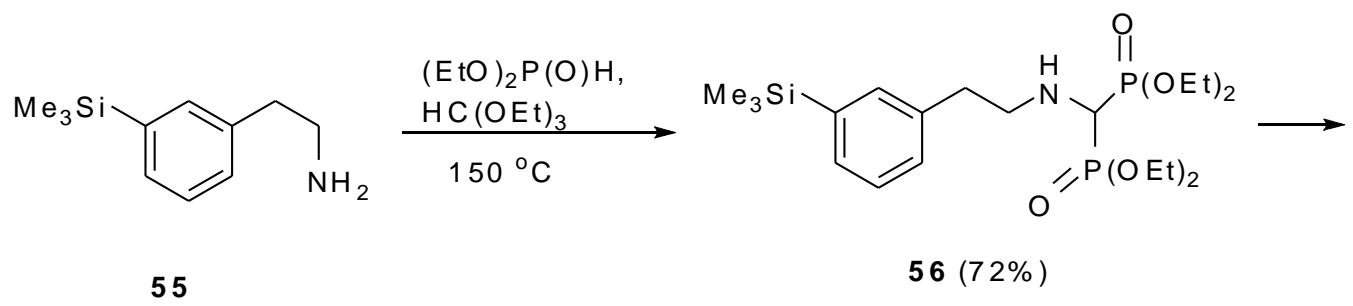

\footnotetext{
1. $\mathrm{TMSBr} / \mathrm{EtOH}$

2. nca $\mathrm{Nal}, \mathrm{AcOH}, \mathrm{TFA}, \mathrm{NCS}$
}<smiles>O=P(=O)C(NCCc1cccc(Br)c1)[PH](=O)O</smiles>

\section{Scheme 21}




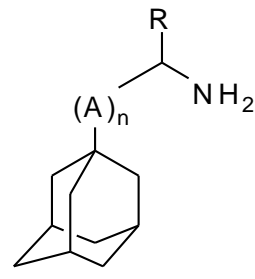

$58 a-d$

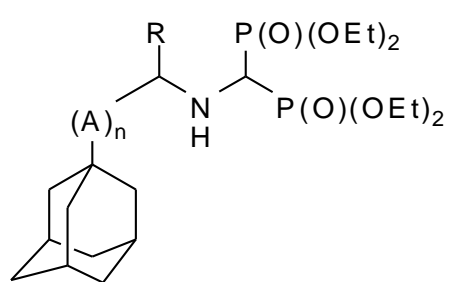

$59 a-d(62-90 \%)$

$\mathrm{R}=\mathrm{H}, \mathrm{n}=\mathrm{O}(\mathbf{a}) ; \mathrm{R}=\mathrm{Ph}, \mathrm{n}=0(\mathbf{b}) ; \mathrm{R}=\mathrm{H}, \mathrm{A}=\mathrm{OCH}_{2}, \mathrm{n}=1$ (c); $\mathrm{R}=\mathrm{Me}$,

$A=\mathrm{CH}_{2}, \mathrm{n}=1$ (d)
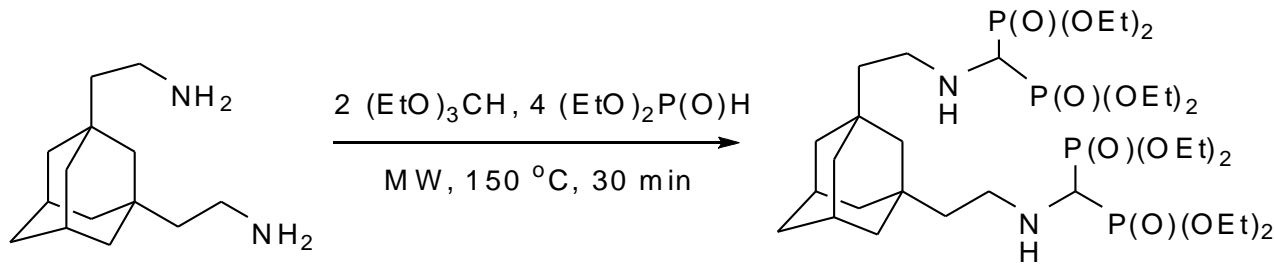

$60(67 \%)$

\section{Scheme 22}

Bisphosphonylation has been also extended to cyclic amines such as aziridine, piperidine or morpholine and various primary $N$-heterylamines (Structure block 2). Approach to more sophisticated $N$-heteryl-substituted 1-aminobisphosphonates is depicted in Scheme 23. Although the conversion of aminopyridines $\mathbf{6 1}$ into the corresponding bisphosphonates proceeded very slowly (incomplete reaction even after $48 \mathrm{~h}$ at $110^{\circ} \mathrm{C}$ ), it allowed the isolation of the pure final products 62 by simple precipitation in $25-65 \%$ yield. ${ }^{93}$

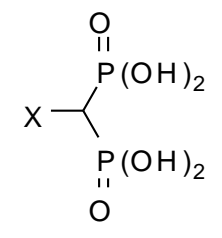

$$
X=
$$

ref. [29] ref. [11] ref. [11,41,85,86] [11] [1] [1]


<smiles>[14CH3]NC(P(=O)=O)[PH](=O)O</smiles>

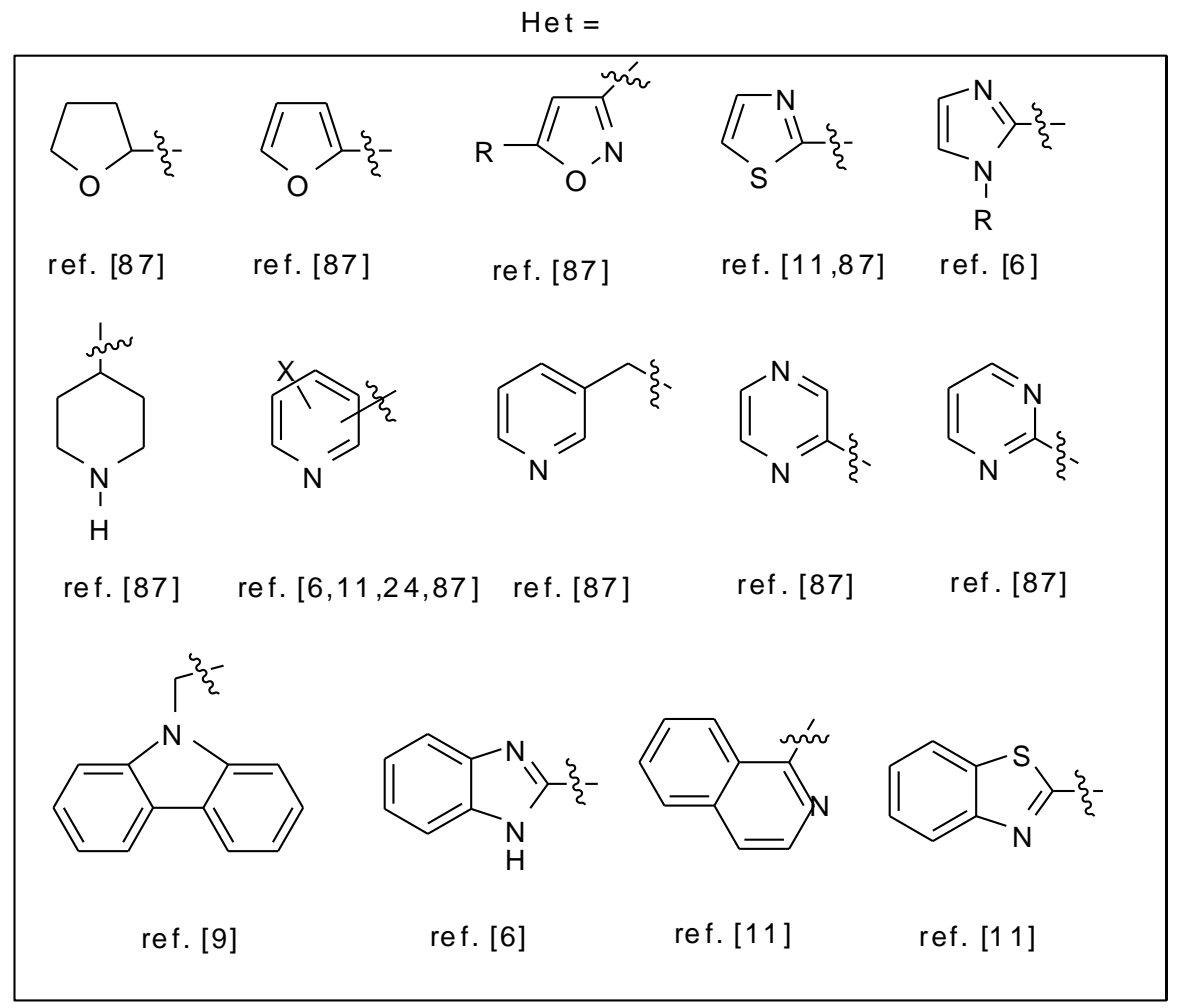

Structure block 2. Heterylamino-substituted 1,1-bisphosphonates
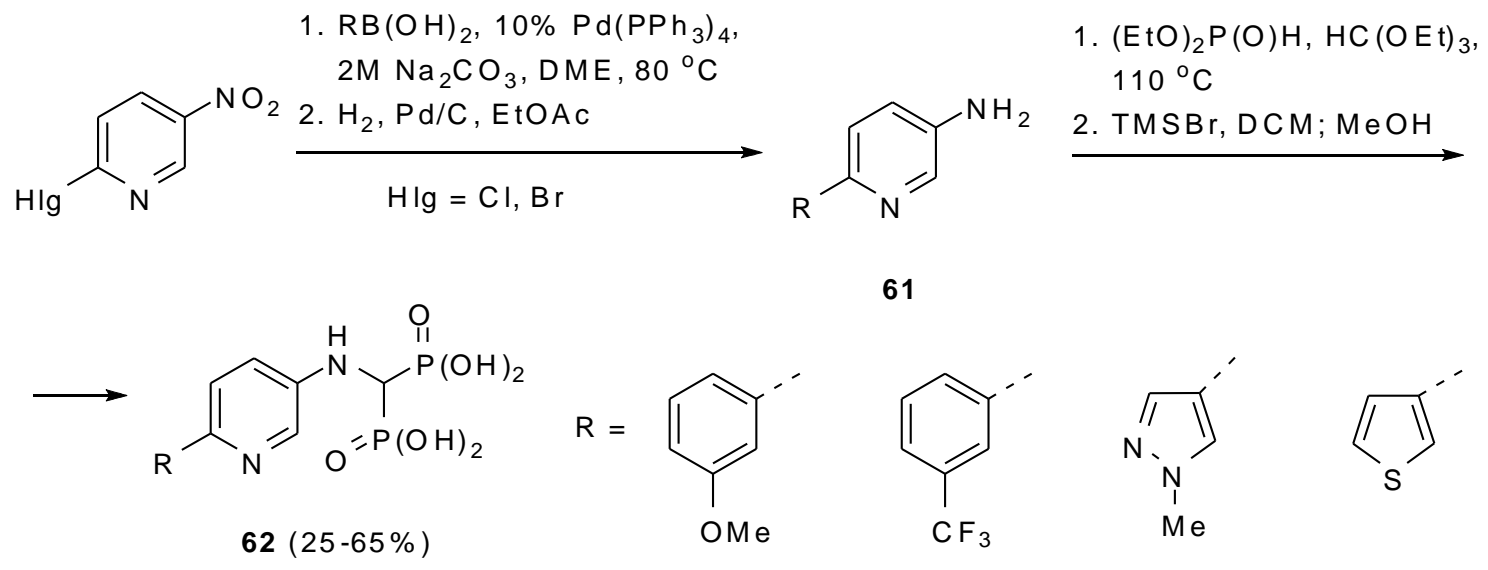

61

\section{Scheme 23}


Of great synthetic importance is the preparation of aminobisphosphonate 64, which are valuable precursor of a wide range of bisphosphonate conjugates. This compound is readily obtained from dibenzylamine, triethyl orthoformate and diethyl phosphite followed by debenzylation with cyclohexene or $\mathrm{H}_{2}$ and $\mathrm{Pd} / \mathrm{C}$ as the catalyst. ${ }^{94}$ Known applications of 64 include the synthesis of the new macrocyclic DOTA-like ligand $\mathbf{6 6}$ containing a bis(phosphonic acid) pendant arm $^{34}$ and potential bone-targeting reagents 67-69 for bone tumors consisting of melphalan linked to a bisphosphonate moiety through an amide linkage (Scheme 24). ${ }^{95}$

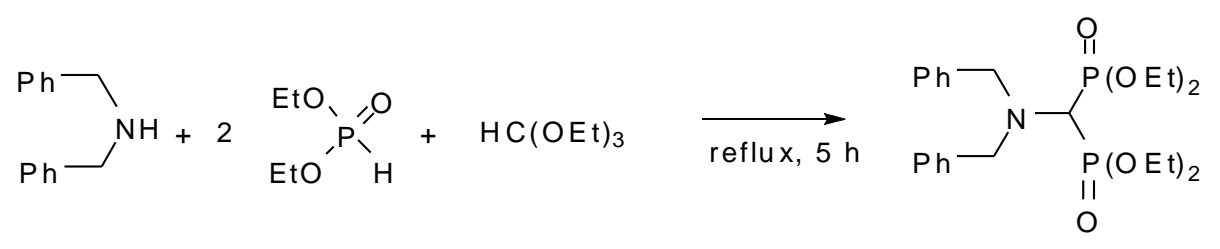

$63(43-59 \%)$

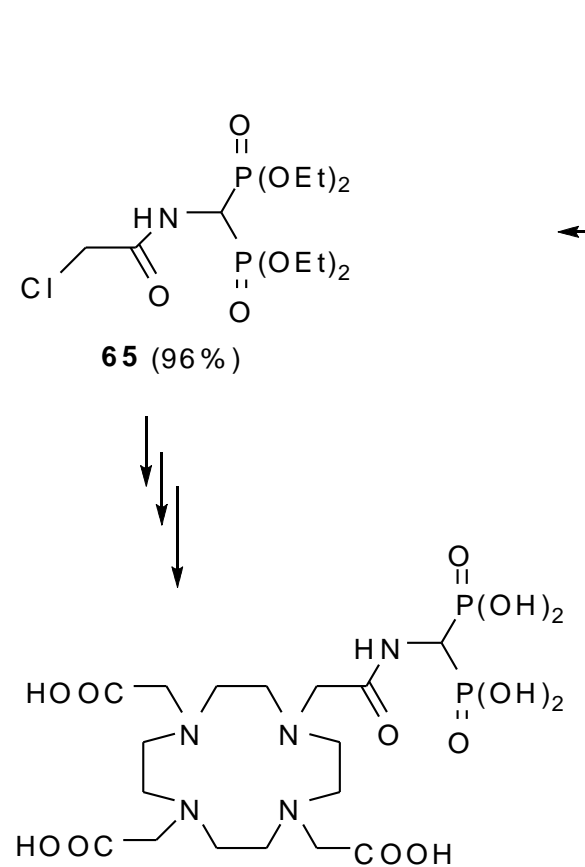

66

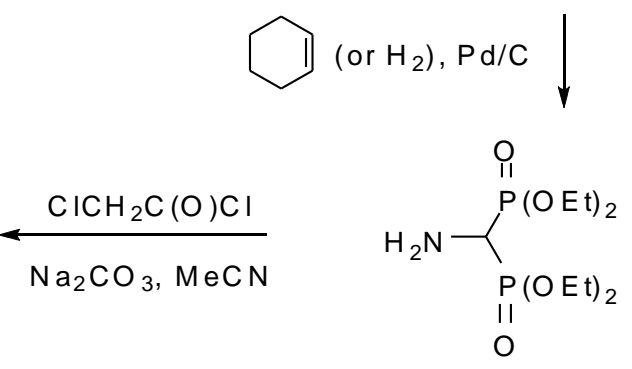

$64(85-100 \%)$
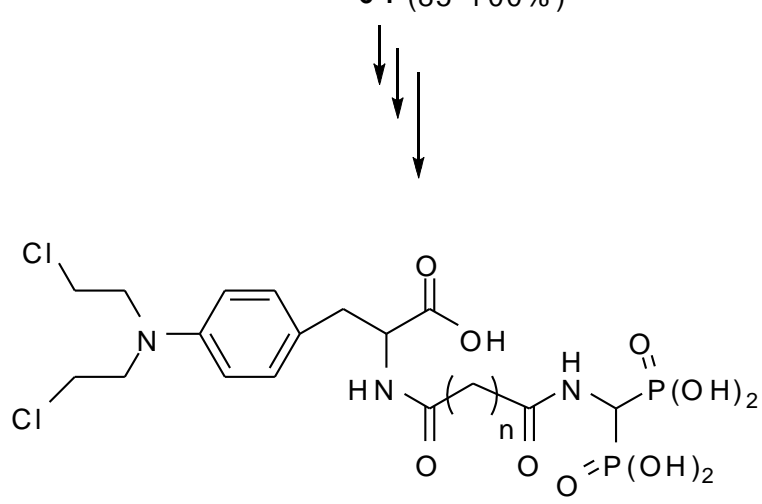

67, $\mathrm{n}=1$

$68, \mathrm{n}=2$

$69, \mathrm{n}=3$

\section{Scheme 24}




\section{Synthesis from imines and related compounds}

As mentioned in previous section, the three component reaction consisting of a primary amine, orthoformate and the half ester of phosphorous acid proceeds via a series of methyleneimine and alkoxymethylphosphonate intermediates. Not surprisingly, some methyleneimine derivatives can be used as independent substrates for the synthesis of specific types of aminobisphosphonates. Thus, Prishchenko et al. ${ }^{96}$ demonstrated the utility of the ethoxymethyleneimines in the synthesis of $\mathrm{N}$-substituted aminomethylenebisphosphonates. They shown that ethoxymethyleneimine 70 reacted with a mixture of $(\mathrm{EtO})_{2} \mathrm{POSiMe}_{3}$ and $(\mathrm{EtO})_{2} \mathrm{P}(\mathrm{O}) \mathrm{H}$ and also with a mixture of $\left(\mathrm{Me}_{3} \mathrm{SiO}\right)_{3} \mathrm{P}$ and $\left(\mathrm{Me}_{3} \mathrm{SiO}\right)_{2} \mathrm{P}(\mathrm{O}) \mathrm{H}$ at $140-160{ }^{\circ} \mathrm{C}$ to form bisphosphonates 71 and 72 (Scheme 25). This synthetic strategy was further developed for the preparation of bisphosphonites. Treatment of formamidine 73 with $\left(\mathrm{Me}_{3} \mathrm{SiO}\right)_{2} \mathrm{PH}$ gave the bisphosphonite 74. This compound was converted after isolation into the symmetrical bisphosphonate $\mathbf{7 5}$ by heating under reflux with hexamethyldisilazane (Scheme 26). Studies were also performed on the synthesis of simple $N, N$-dialkylaminophosphonates starting from bromomethyleneiminium salts. For example, the reaction of commercially available iminium salts $\left[\mathrm{BrCH}=\mathrm{NAlk}_{2}\right]^{+} \mathrm{Br}^{-}$with 2 equiv. of $(\mathrm{MeO})_{3} \mathrm{P}$ gives rise to the bisphosphonates $\mathrm{Alk}{ }_{2} \mathrm{~N}-\mathrm{CH}\left(\mathrm{PO}_{3} \mathrm{Me}_{2}\right)_{2}$ in high yields. ${ }^{97}$

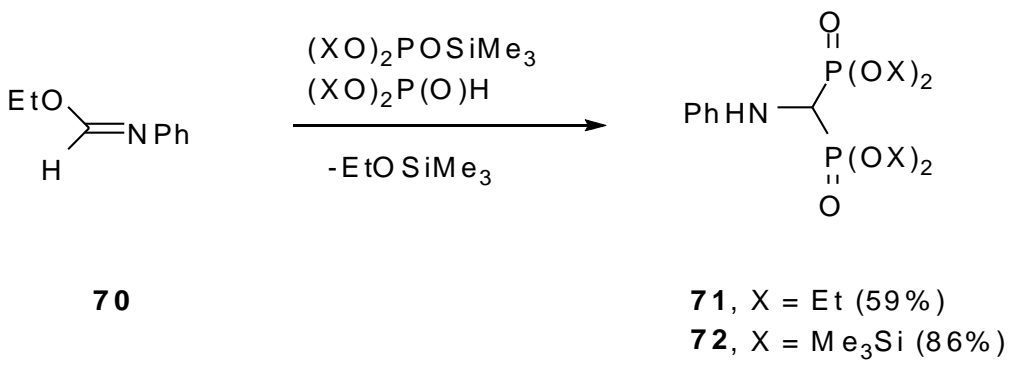

\section{Scheme 25}

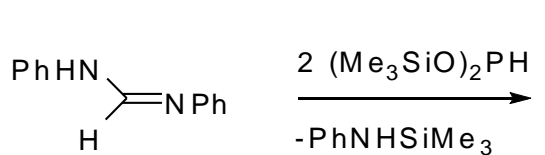

73

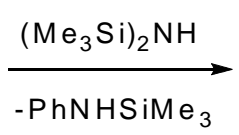

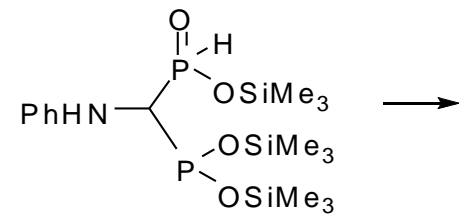

74 (83\%)

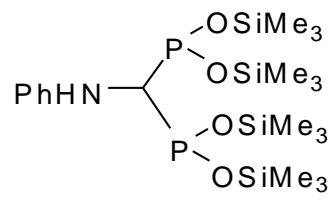

$75(78 \%)$

\section{Scheme 26}


A convenient methodology for the synthesis of $\gamma$-phosphono- $\alpha$-aminobisphosphonates 77 was developed from 4-phosphono-1-aza-1,3-dienes 76 (Scheme 27). Double nucleophilic addition of silylated dialkylphosphites onto the azadienes $\mathbf{7 6}$ in the presence of sulfuric acid leads to compounds $\mathbf{7 7}$ in good yields. The regiochemistry of the reaction is dependent on the steric demand of the group on nitrogen. For example, in the case of the $N$ - $t$-Bu derivative, a tandem 1,4 /1,2-addition of silylated phosphite leading to the $\alpha$-aminophosphonate $\mathbf{7 8}$ was observed. ${ }^{98}$ In the reaction of imidoyl chloride 79 derived from $\mathrm{FCH}_{2} \mathrm{C}(\mathrm{O}) \mathrm{NHC}(\mathrm{O}) \mathrm{CCl}_{3}$ and $\mathrm{PCl}_{5}$ with diphenyl phosphite the substitution of chlorine atom by the phosphonate group is accompanied by the 1,2-addition to the $\mathrm{C}=\mathrm{N}$ bond affording the bisphosphonate $\mathbf{8 0}$ (Scheme 28). ${ }^{99}$ Similar reactions have been described for trifluoroacetimidoyl chlorides $\mathrm{F}_{3} \mathrm{CC}(\mathrm{Cl})=\mathrm{NSO}_{2} \mathrm{Ar}^{100}$

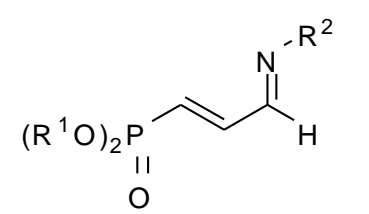

76

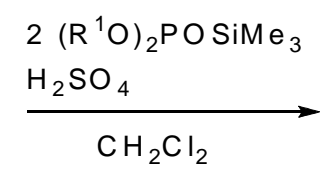

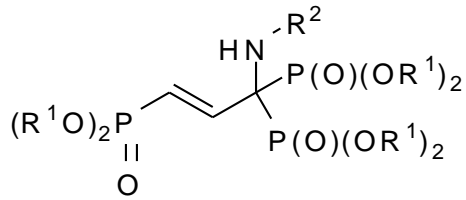

$77(44-76 \%)$

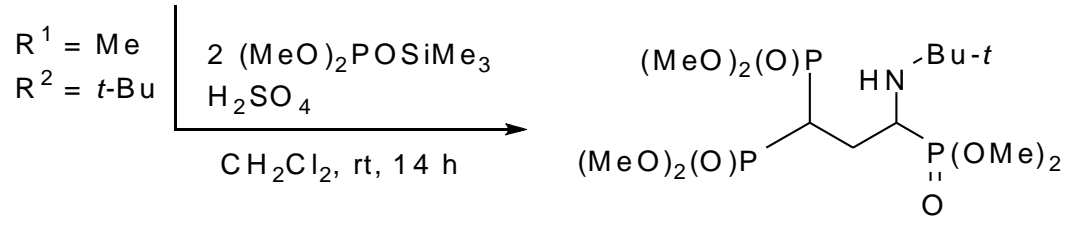

$78(54 \%)$

\section{Scheme 27}

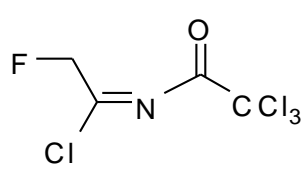

79

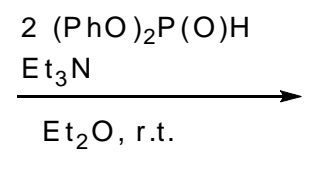

$$
(\mathrm{PhO})_{2}(\mathrm{O}) \mathrm{P}
$$

$80(35 \%)$

\section{Scheme 28}

In 1994, Shibuya and co-workers found a new synthetic route to conformationally constrained 1-aminomethyle-1,1-bisphosphonates via Beckmann rearrangement of oximes $\mathbf{8 1}$ in the presence of phosphorus nucleophiles $\left[(\mathrm{EtO})_{3} \mathrm{P}\right.$ or $\left.(\mathrm{EtO})_{2} \mathrm{P}(\mathrm{O}) \mathrm{H}\right]$ using $\mathrm{POCl}_{3}$ as a promoter (Scheme 29). ${ }^{33}$ In this reaction the phosphorus nucleophiles capture both the intermediate iminocarbocations and iminophosphonates to give bisphosphonate derivatives 82a-e. Bisphosphonylation reaction of aromatic oxime $\mathbf{8 3}$ gave the bisphosphonate $\mathbf{8 4}$ regioselectively with migration of the aromatic groups upon using $(\mathrm{EtO})_{3} \mathrm{P}$ as a phosphorus reagent. Later a 
Chinese research group applied the same methodology as depicted in Scheme 29 to synthesize aminomethylene-1,1-bisphosphonates via one-pot reaction using ketones, hydroxylamine hydrochloride, phosphorus trichloride and water as starting materials. ${ }^{101}$

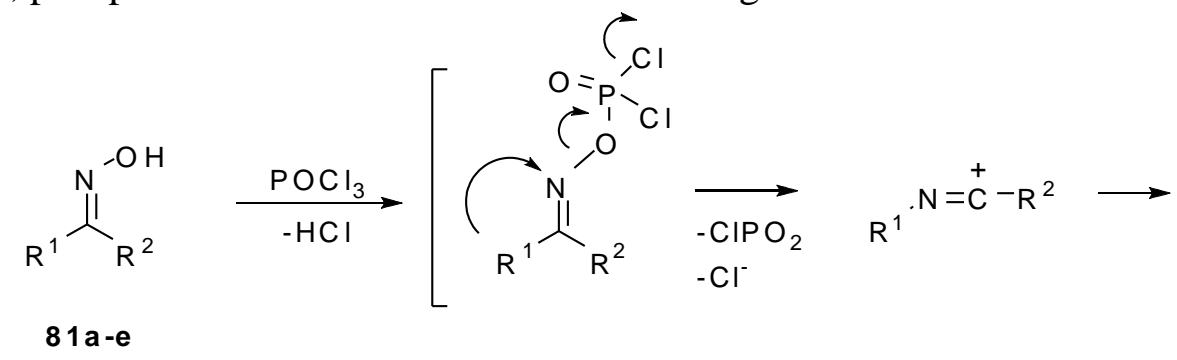

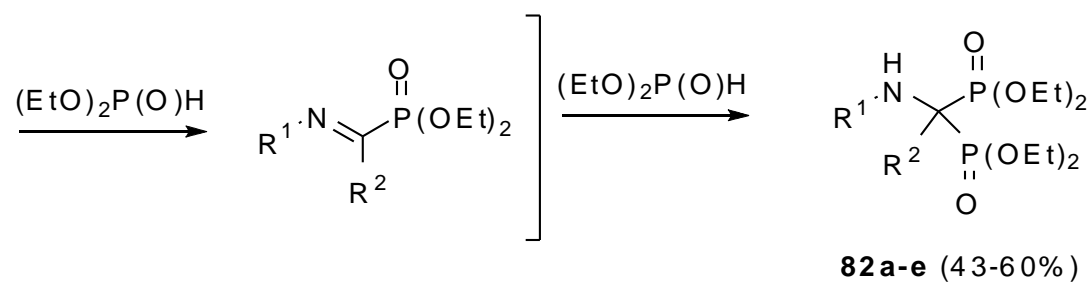
a: $R^{1}=R^{2}=-\left(\mathrm{CH}_{2}\right)_{4}-$
b: $R^{1}=R^{2}=-\left(\mathrm{CH}_{2}\right)_{5}$
c: $R^{1}=P h, R^{2}=M e$
d: $R^{1}=P h, R^{2}=E t$
e: $\mathrm{R}^{1}=4-\mathrm{MeOC}_{6} \mathrm{H}_{4}, \mathrm{R}_{2}=\mathrm{Me}$<smiles>O/N=C1\CCCc2ccccc21</smiles>

83

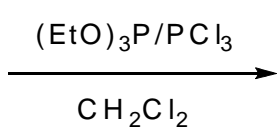

$\mathrm{CH}_{2} \mathrm{Cl}_{2}$

\section{Scheme 29}

\section{Block building syntheses}

In this group, a target aminomethylenebisphosphonate has been obtained from a pre-existing aminobisphosphonate molecule by synthetic adjustment such as acetylation, alkylation, phosphorylation, imination and other transformations. Such reactions open an effective route to bisphosphonate derivatives which can be used as precursors for the construction of bisphosphonated prodrugs and aminomethylenebisphosphonate conjugates.

1-Aminomethylene-1,1-bisphosphonates can sometimes be easily converted into the bisphosphonic prodrugs by a simple coupling between the amine and carboxyl functions. Thus, 
gem-bisphosphonic methotrexate conjugate 87 used to treat animal models of Walkers osteosarcoma has been prepared from acid 85 and bisphosphonate $\mathbf{6 4}$ followed by the coupling with 2,4-diamino-6-bromomethylpteridine. Hydrolysis of the phosphonic ester $\mathbf{8 6}$ took place via transsilylation with bromotrimethylsilane followed by methanolysis (Scheme 30). ${ }^{102}$
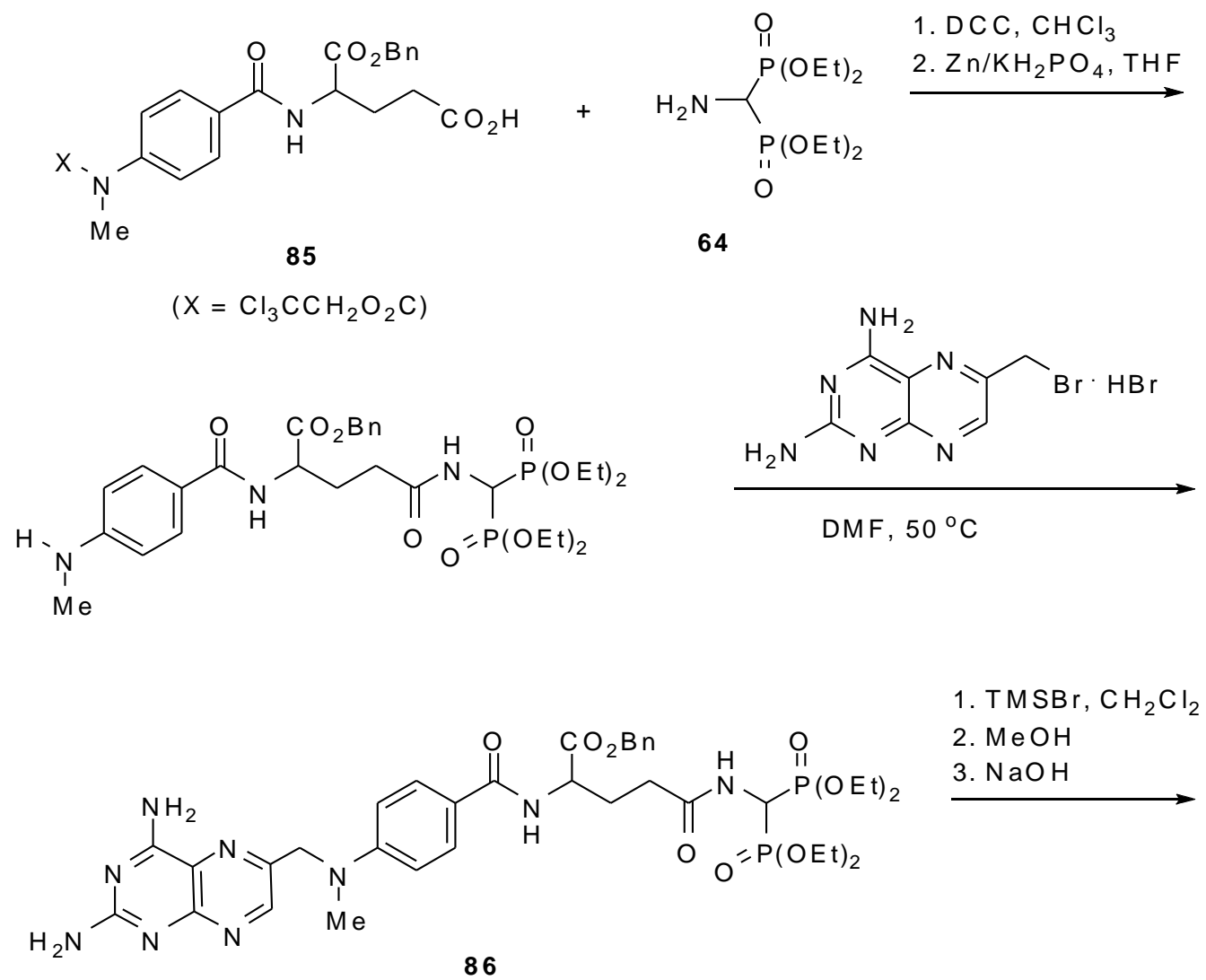<smiles>[Y19]N(Cc1cnc2nc(N)nc(N)c2n1)c1ccc(C(=O)NC(CCC(=O)NC(P(=O)(O)O)P(=O)(O)O)C(N)=O)cc1</smiles>

87

\section{Scheme 30}

Similar amidation reaction was applied for the synthesis of estradiol-bisphosphonate conjugates ( $\mathrm{E}_{2}$-BPs) 88-93 in which the linkers were sensitive to esterases, proteases, and acidic conditions on bones to act as bone-seeking $\mathrm{E}_{2}$ prodrugs. Among them, conjugate 93 (MCC-565) was found to be the most effective and specific for bones (Structure block 3). ${ }^{103}$ 


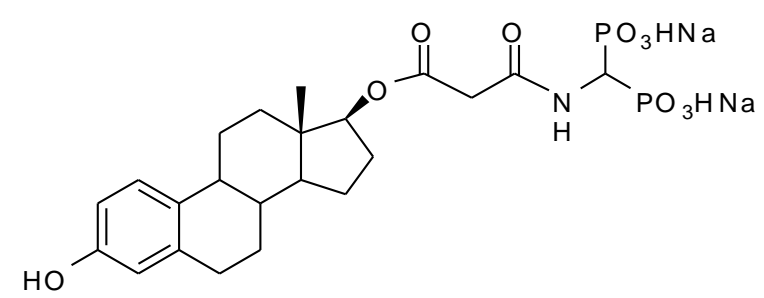

88

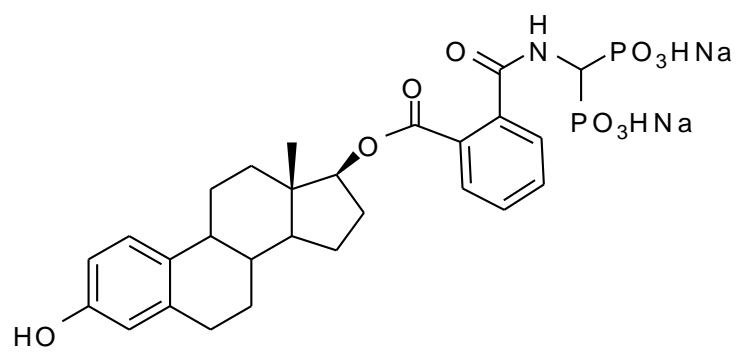

90

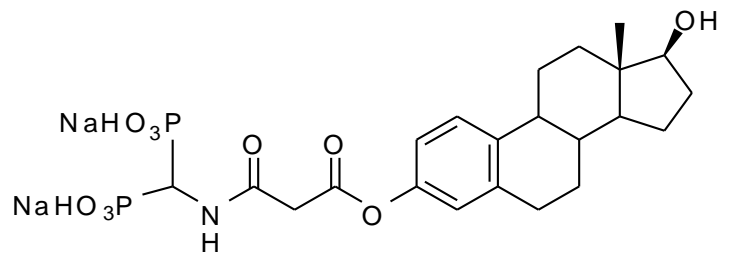

92

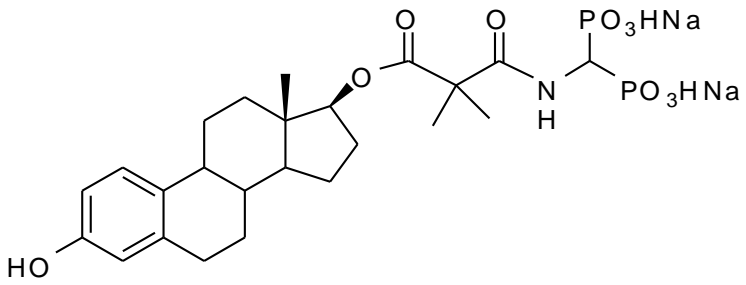

89

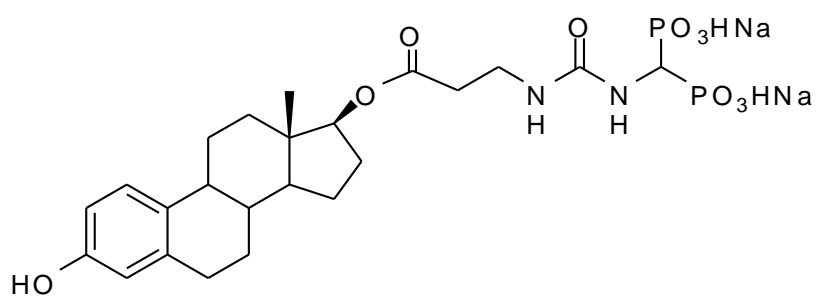

91

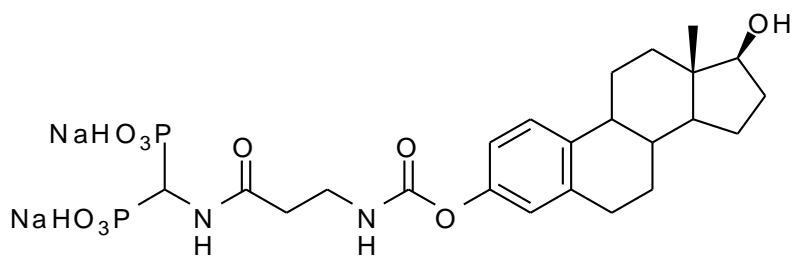

93 (MCC-565)

Structure block 3. Estradiol-bisphosphonate conjugates ( $\left.\mathrm{E}_{2}-\mathrm{BPs}\right)$

With regards to bisphosphonated benzoxazinorifamycin prodrugs for the prevention and treatment of osteomyelities, several approaches were applied one of which is summarized in Scheme 31. ${ }^{104} \mathrm{~N}$-Protected amino alcohol 94 was treated with succinic anhydride to produce the succinic acid monoester, which was coupled with 1-aminomethylenebisphosphonate $\mathbf{6 4}$ under standard peptide-coupling conditions. The bisphosphonate intermediate 95 was then used in the condensation with the silylated rifamycin precursor 96 to provide bisphosphonated rifamycin prodrug 97. Effectiveness of the latter has been estimated by in vitro tests.

Lecouvey s group has developed a method for the synthesis of new polydentate ligands for metal chelating therapy containing 1-hydroxy-2-pyridinone and bisphosphonate moieties linked via an amide function. Interestingly, the length of the carbon chain between the amino and the methylene bisphosphonate groups has a strong effect on the dealkylation of esters 98 by concentrated $\mathrm{HCl}$. Refluxing 98a in concentrated $\mathrm{HCl}$ leads to the splitting of the amide bond and the formation of free 1-aminomethylenebisphosphonic acid. In contrast, when at least two 
carbon atoms are present between the amino group and the tetraethyl methylenebisphosphonate moiety as in ester $\mathbf{9 8 b}$, dealkylation by concentrated $\mathrm{HCl}$ gives the mixed bisphosphonatehydroxy pyridonate ligand 99 in almost quantitative yield (Scheme 32). ${ }^{105}$

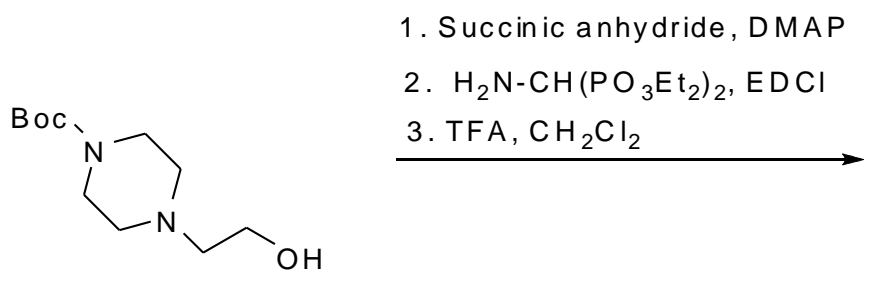

94

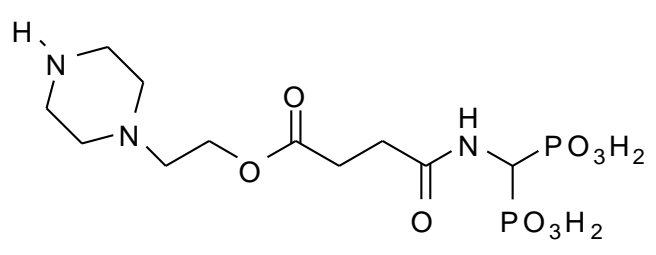

95

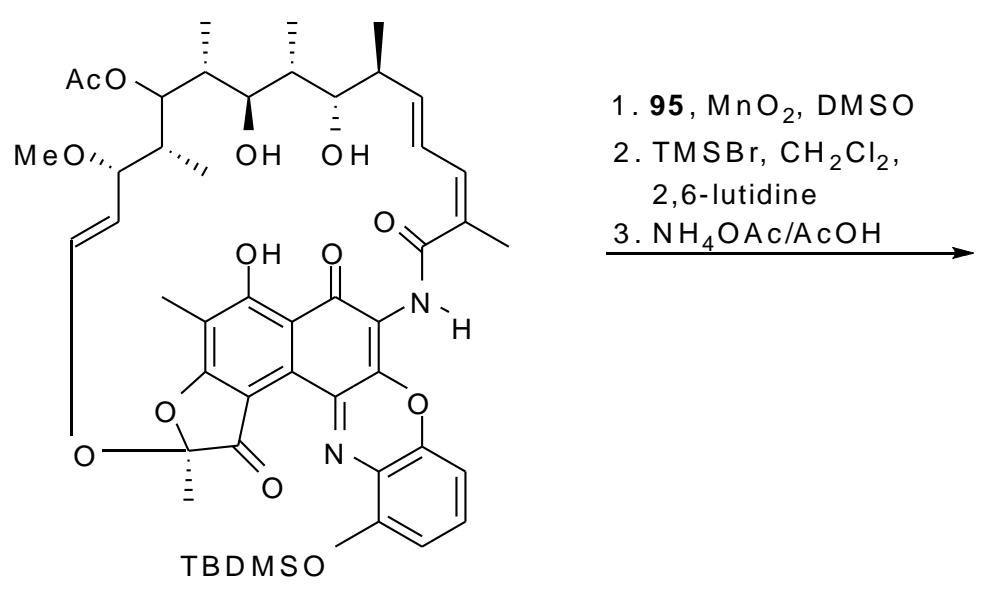

96

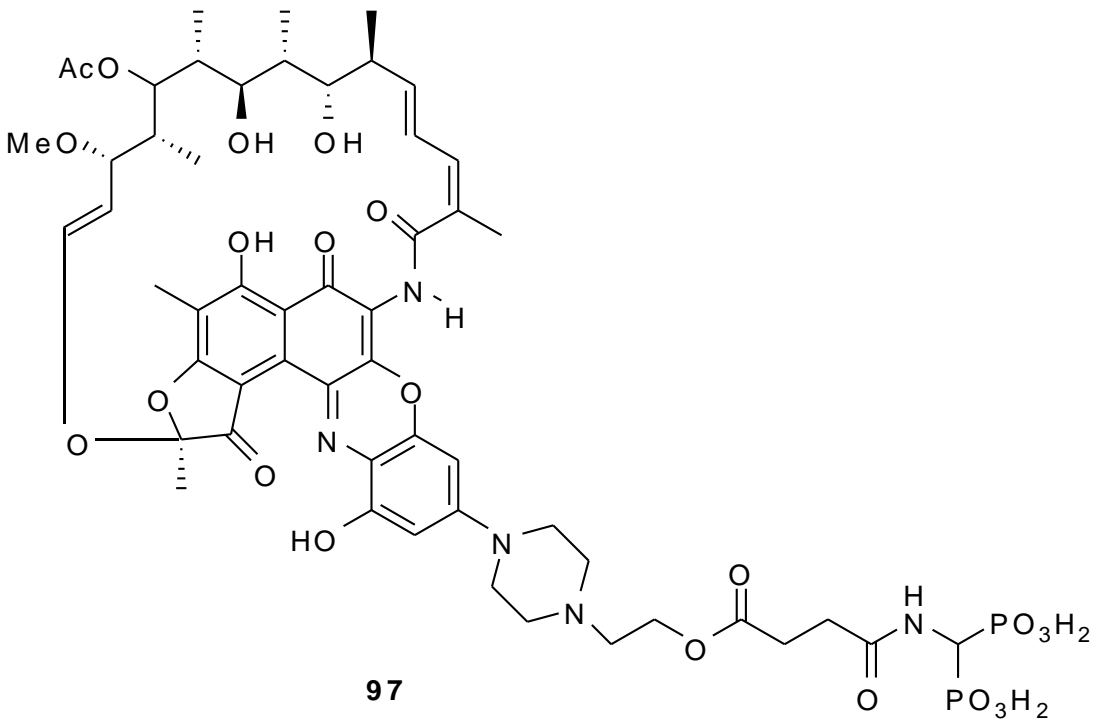

$E D C I=1$-eth yl-3-(3-dim ethylam in op ropyl)carbodiim ide hyd roch loride

\section{Scheme 31}


The synthesis of bisphosphonate diethylenetriaminepentaacetic acid (DPTA) derivative 100 was accomplished by treating aminobisphosphonate 64 with diethylenetriaminepentaacetic dianhydride in DMF at 50-60 ${ }^{\circ} \mathrm{C}$ followed by hydrolysis of 100 (Scheme 33). The DTPA conjugate $\mathbf{1 0 1}$ retains bone-binding character and is able to act as a carrier of cytotoxic radionuclides. ${ }^{106}$

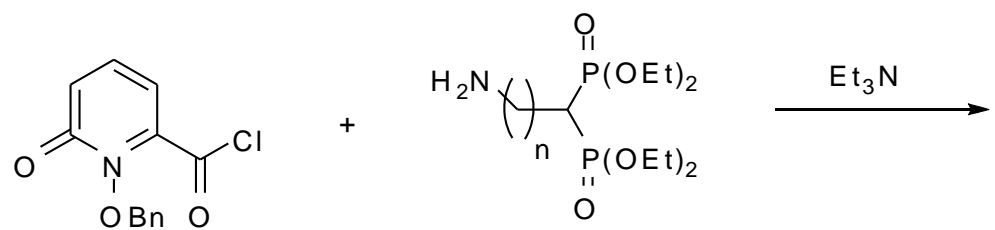

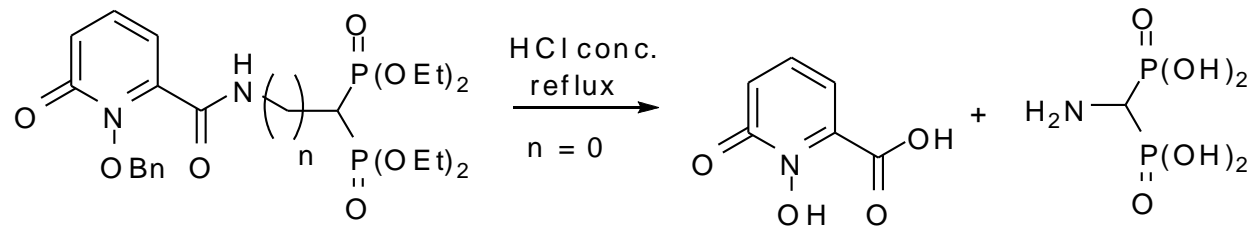

$98 \mathbf{a}, \mathrm{n}=0$

$98 \mathrm{~b}, \mathrm{n}=2$

$\underset{\mathrm{HCI} \text { conc. }}{\operatorname{reflux}} \downarrow \mathrm{n}=2$<smiles>O=C(NCCC([PH](=O)O)P(=O)(O)O)c1cccc(=O)n1O</smiles>

99

Scheme 32

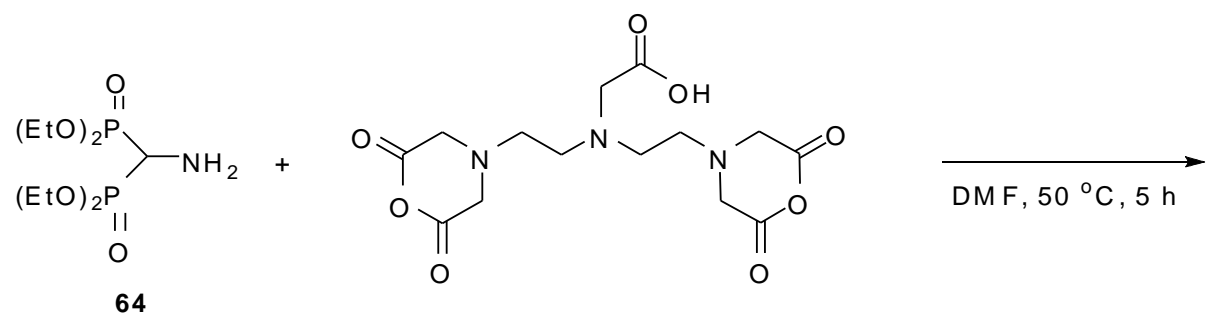<smiles>CCO[PH](=O)C([PH](=O)NC(=O)CN(CCN(CCN(CC(=O)O)CC(=O)O)CC(=O)O)CC(=O)O)[PH](=O)OCC</smiles>

$100(67 \%)$

$101(90 \%)$

\section{Scheme 33}


Catechol-bisphosphonate conjugates $\mathbf{1 0 4}$ for metal intoxication therapy were obtained by condensation of aminobisphosphonate 64 with dihydroxybenzaldehyde 102 followed by reduction with $\mathrm{NaBH}(\mathrm{OAc})_{3}$ prepared in situ. Hydrolysis of bisphosphonic esters $\mathbf{1 0 3}$ was carried out by using bromotrimethylsilane followed by methanolysis (Scheme 34). ${ }^{107}$
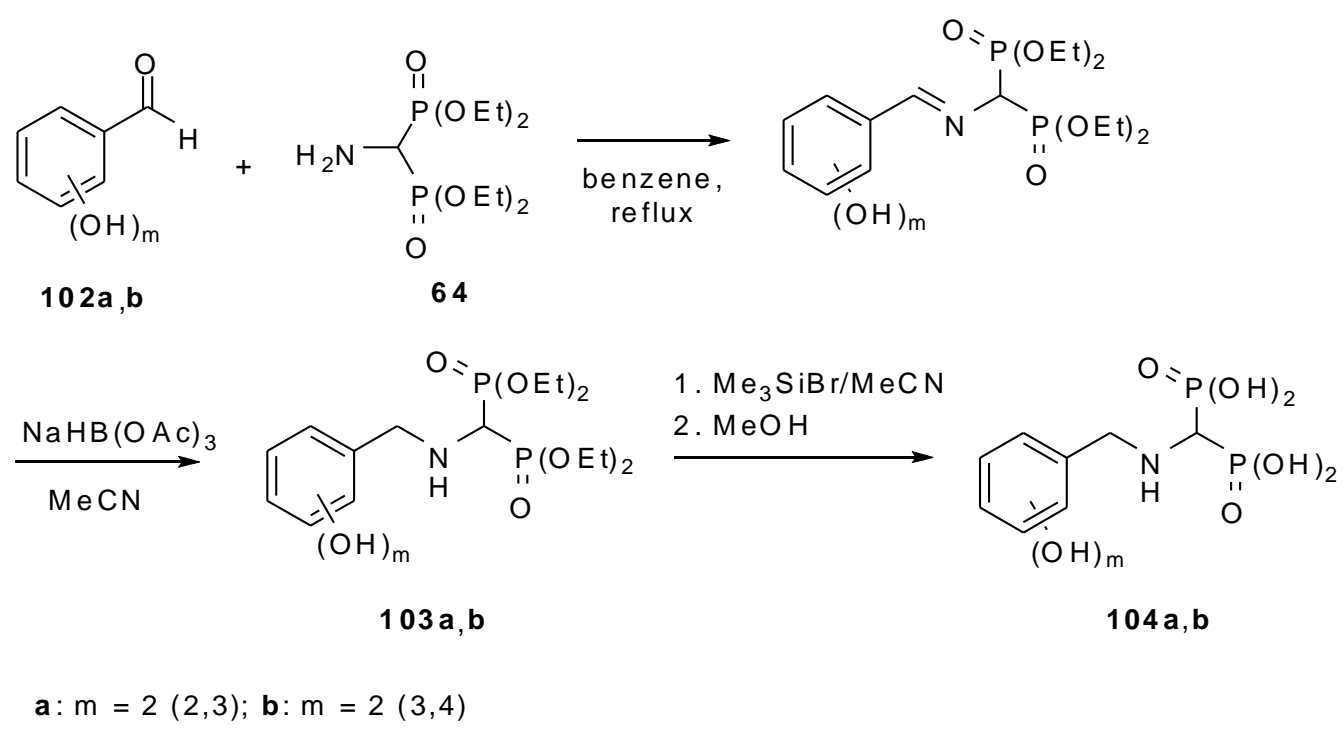

\section{Scheme 34}

A variety of thioureido derivatives of methylenebisphosphonic acid was synthesized by the reaction of 1-aminomethylene-1,1-bisphosphonic acid with isothiocyanates (Scheme 35). In the free form the resulting compounds $\mathbf{1 0 5}$ are unstable, except for acid bearing 4dimethylaminophenyl substituent $\left(\mathrm{R}=4-\mathrm{Me}_{2} \mathrm{NC}_{6} \mathrm{H}_{4}\right)$ which exists as an internal salt. However, thioureido derivatives could be isolated as disodium salts $\mathbf{1 0 6}^{108}$ and their herbicidal action ${ }^{109}$ as well as effect on the activity of alkaline phosphatases from bovine small intestine mucosa and human placenta ${ }^{110}$ were studied. It is worst mentioning that due to the partial double bond character of the SC-N bond thioureidobisphosphonates exist in solutions as mixtures of the $E$ and $Z$ isomers whose ratio is strongly $\mathrm{pH}$-dependent. ${ }^{111}$ Substituted thioureidomethylenebisphosphonic acids react with haloketones to form thiazoles. ${ }^{112-114}$

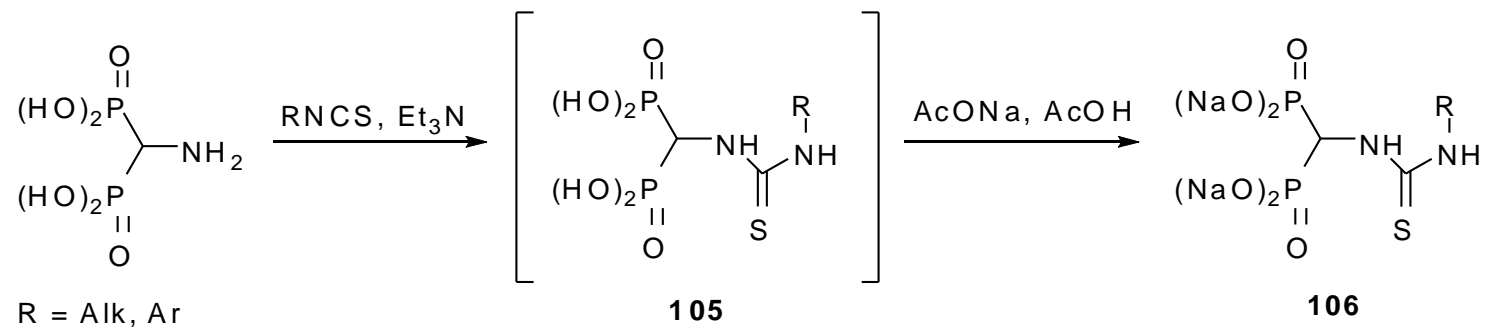

\section{Scheme 35}


Isocyanatomethylenebisphosphonate $\mathbf{1 0 7}$ was demonstrated to be an interesting starting building block giving access to drugs for the treatment of metastatic bone cancer. ${ }^{106}$ For example, bisphosphonate conjugate with 5-fluorouracil was synthesized as outlined in Scheme 36. The urea linkage in compound $\mathbf{1 0 9}$ is possible functional group that may undergo biochemical cleavage to release the conjugated 5-fluorouracil and provide local concentration necessary for tumor therapy. Bisphosphonate conjugate $\mathbf{1 1 0}$ with the potential for targeted therapy for cancer patients was prepared using a reaction between the isocyanatobisphosphonate 107 and the potent anticancer drug gemcitabine $\left(\right.$ Gemzar $\left.^{\circledR}\right)($ Scheme 37$) .^{115}$<smiles>CCOC(=O)C(N)[PH](=O)OCC</smiles>

64

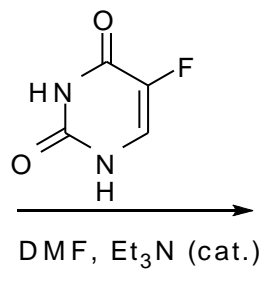<smiles>CCO[PH](=O)C(N=O)P=O</smiles>

$107(89 \%)$

\section{Scheme 36}

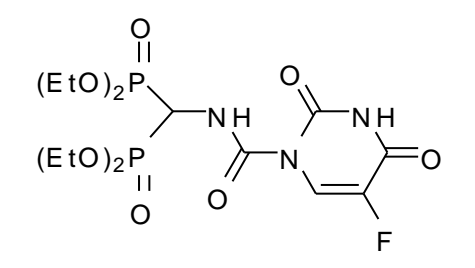

$108(76 \%)$

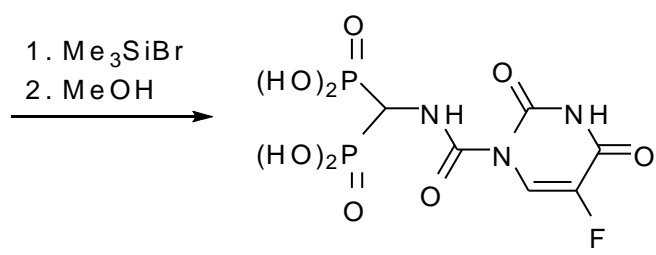

$109(90 \%)$

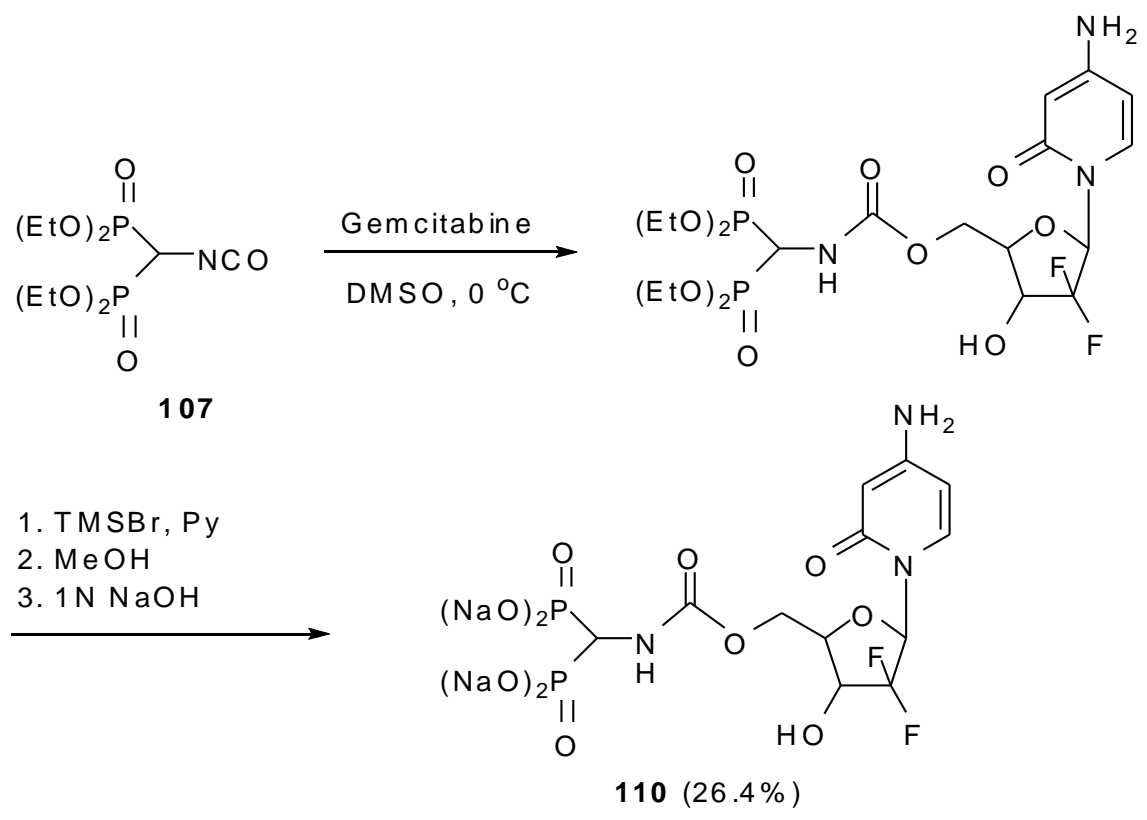

\section{Scheme 37}


The reaction of 1-aminomethylenebisphosphonate 64 with carbonyl compounds provides a very general route to bisphosphonated imines and various new aminophosphonate derivatives. For example, after condensation of 64 with aldehydes and cyclic ketones, the resulting imines 111 can be used as intermediates in the preparation of aminobisphosphonate derivatives $\mathbf{1 1 2}$ by reduction of the imino linkage with $\mathrm{NaBH}(\mathrm{OAc})_{3}$ (Scheme 38) as well as in the synthesis of 2aza-1,3-butadienes 113 by means of a Wadsworth-Emmons reaction (Scheme 39). ${ }^{116}$ The olefination reaction of imines 111 can be carried out using different bases including MeLi, BuLi and $\mathrm{Bu}^{\mathrm{t}} \mathrm{OLi}$ but as might be expected a weaker base such as cerium carbonate in $\mathrm{THF} / \mathrm{Pr}^{\mathrm{i}} \mathrm{OH}$ provided good yields of azadienes 113. This methodology has been applied to the synthesis of azatrienes 114 and 115. ${ }^{116}$

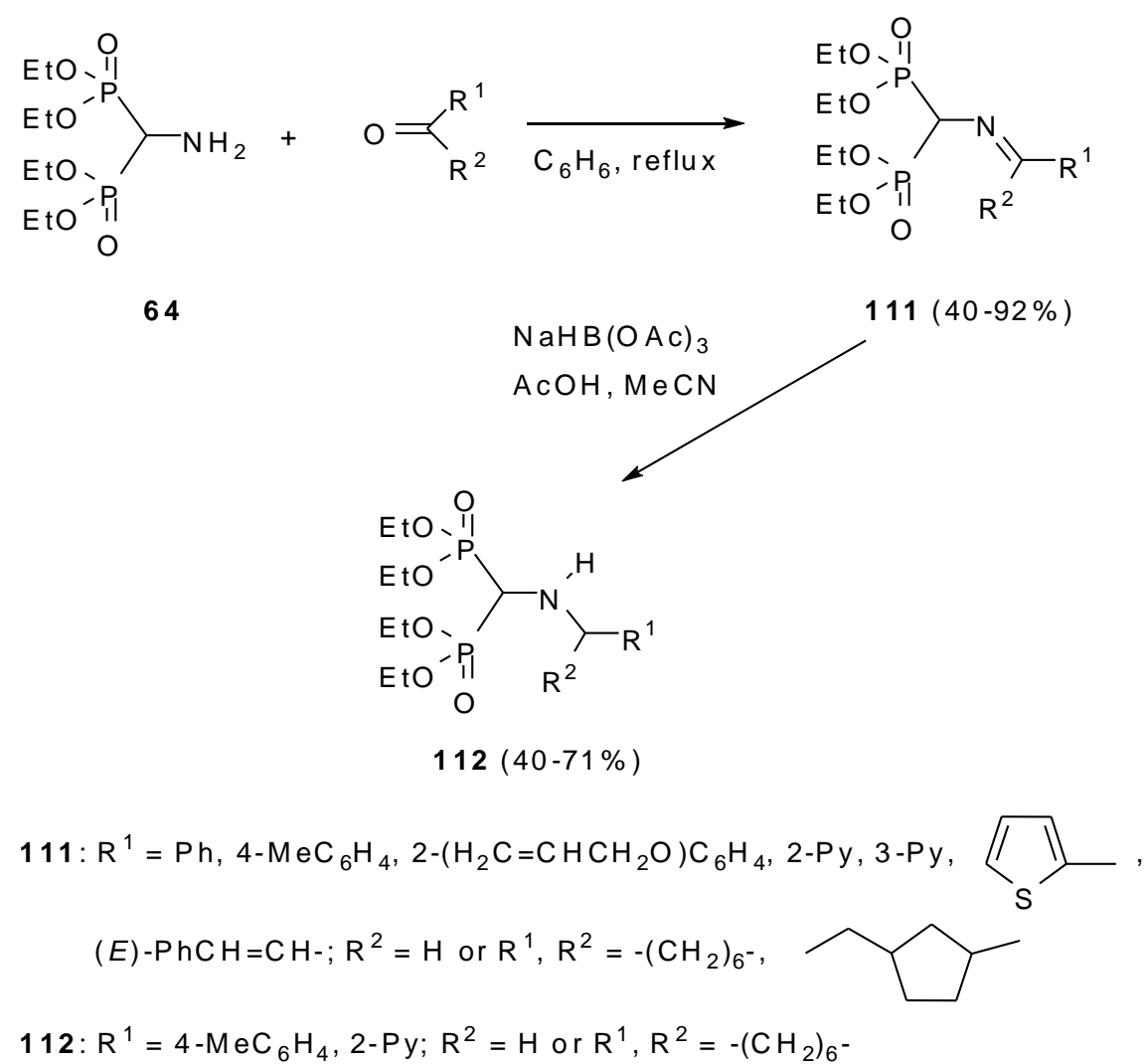

\section{Scheme 38}

3-Amino-3,3-diphosphonopropanoic acid 118 was synthesized by alkylation of the imine 111a. The latter was treated with $\mathrm{K}_{2} \mathrm{CO}_{3} / \mathrm{Bu}_{4} \mathrm{NBr}$ and methyl bromoacetate to give the crude imine 116 in $91 \%$ yield. The target molecule 118 was obtained after stepwise hydrolysis of 116 (Scheme 40). To prepare the homologue, imine 111a was treated with EtONa and ethyl acetate in ethanol at $80{ }^{\circ} \mathrm{C}$ to furnish the imine 119 in $98 \%$ yield. Acidic hydrolysis of the imine 119 afforded the pyrrolidinone $\mathbf{1 2 0}$ which was further transformed into 5-oxopyrrolidine-2,2diyldiphosphonic acid 121 by treatment with $6 \mathrm{~N} \mathrm{HCl}$ (Scheme 41). ${ }^{117}$ 


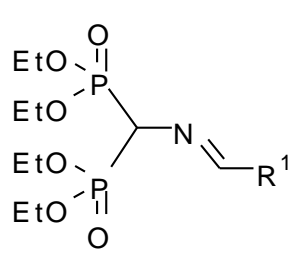

111
1. Base

2. $\mathrm{R}^{2} \mathrm{CHO}$

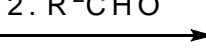

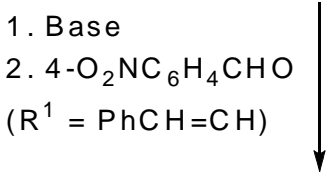

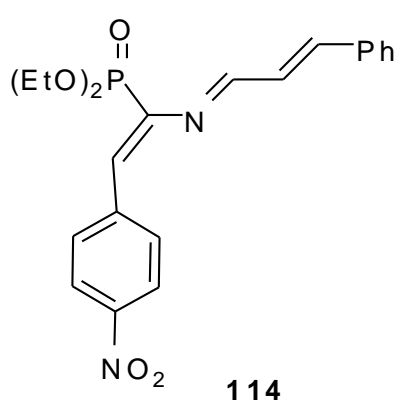

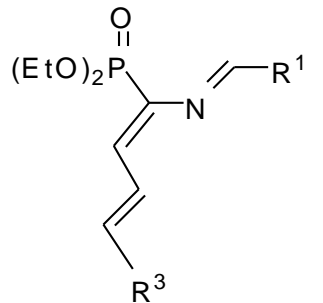

115

$$
\begin{aligned}
& \mathrm{R}^{1}=\mathrm{Ph}, 4-\mathrm{MeC}_{6} \mathrm{H}_{4}, 2-\left(\mathrm{H}_{2} \mathrm{C}=\mathrm{CHCH}_{2} \mathrm{O}\right) \mathrm{C}_{6} \mathrm{H}_{4}, 2-\mathrm{Py}, 3-\mathrm{Py}, \\
& \mathrm{R}^{2}=\mathrm{H}, \mathrm{Me}, \mathrm{Ar}, 2-\mathrm{Py}, 3-\mathrm{Py} ; \mathrm{R}^{3}=\mathrm{Me}, \mathrm{Ph}
\end{aligned}
$$

\section{Scheme 39}
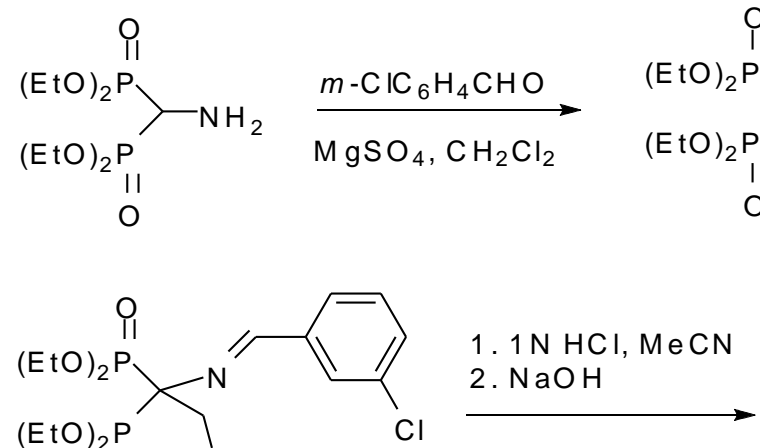

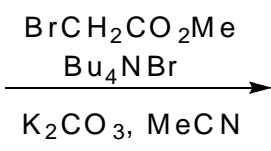

111 a $(70 \%)$

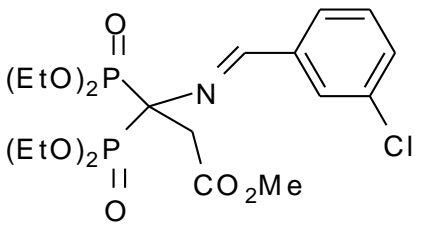

$116(91 \%)$
$117(76 \%)$

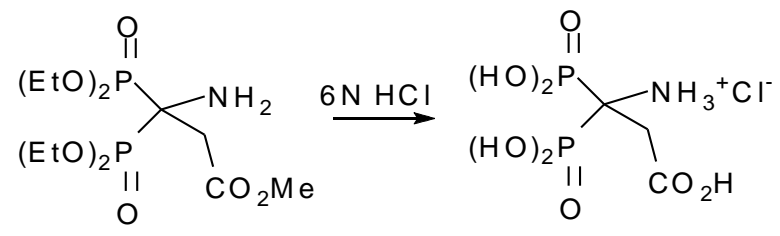

118

\section{Scheme 40}




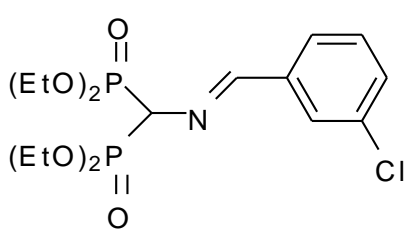

$111 \mathrm{a}$
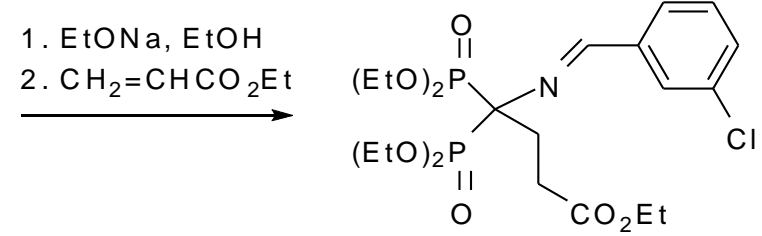

$119(98 \%)$

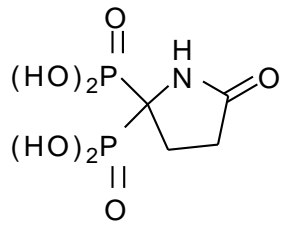

$121(100 \%)$

\section{Scheme 41}

Free 1-aminomethylenebisphosphonic acids do not appear to participate readily in the reactions with aldehydes. Particularly, attempts to prepare imino derivatives from 1aminoethylidene-1,1-bisphosphonic acid $\mathrm{H}_{2} \mathrm{~N}(\mathrm{Me}) \mathrm{C}\left(\mathrm{PO}_{3} \mathrm{H}_{2}\right)_{2}$ have not been successful. However, aromatic aldehydes could be iminated with tetrasodium salts $\mathrm{H}_{2} \mathrm{~N}(\mathrm{Me}) \mathrm{C}\left(\mathrm{PO}_{3} \mathrm{Na}_{2}\right)_{2}$ to give the corresponding imino derivatives in moderate yields. ${ }^{118}$

Aminobisphosphonate $\mathbf{3 1}$ was recently used as an amine component in the multicomponent Petasis boronic acid Mannich reaction. The coupling of $\mathbf{3 1}$ with glyoxylic acid monohydrate and styryl-, aryl- or heterylboronic acid leads to amino acids $\mathbf{1 2 2}$ without detection of any intermediate products (Scheme 42). The method affords the useful access to polyfunctional molecules bearing both amino acid and aminophosphonic acid moieties. ${ }^{119}$

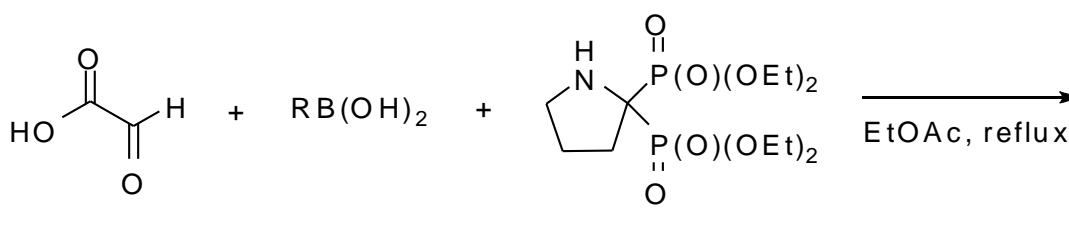

31

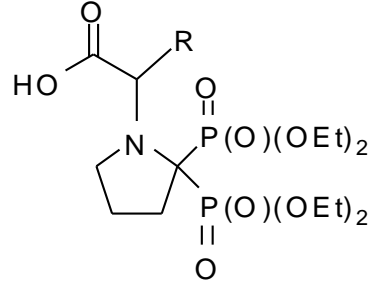

$122(47-80 \%)$<smiles>COc1ccc(C)cc1</smiles><smiles>Cc1ccc2c(c1)OCO2</smiles><smiles>Cc1cccs1</smiles>

\section{Scheme 42}


An interesting synthesis of bisphosphonates 125 substituted at the $\alpha$-position both an amino and an allylic group has been proposed from 1-dimethylamino-1,1-bisphosphonate (Scheme 43). The key step of the synthesis was postulated [2,3]-Wittig rearrangement of the corresponding $N$ allylic ammonium salts $\mathbf{1 2 4}$ prepared by quaternization of the bisphosphonate $\mathbf{1 2 3}$ with allylic halides in the presence of $\mathrm{AgBF}_{4}$. The rearrangement has been realized by treatment of compounds 124 with $\mathrm{NaH}$ in THF. In the case of the prenyl derivative 124e, rearranged product 125 was not detected, and the bisphosphonate 123, stemming from the competitive process was the sole product of the reaction. ${ }^{120}$

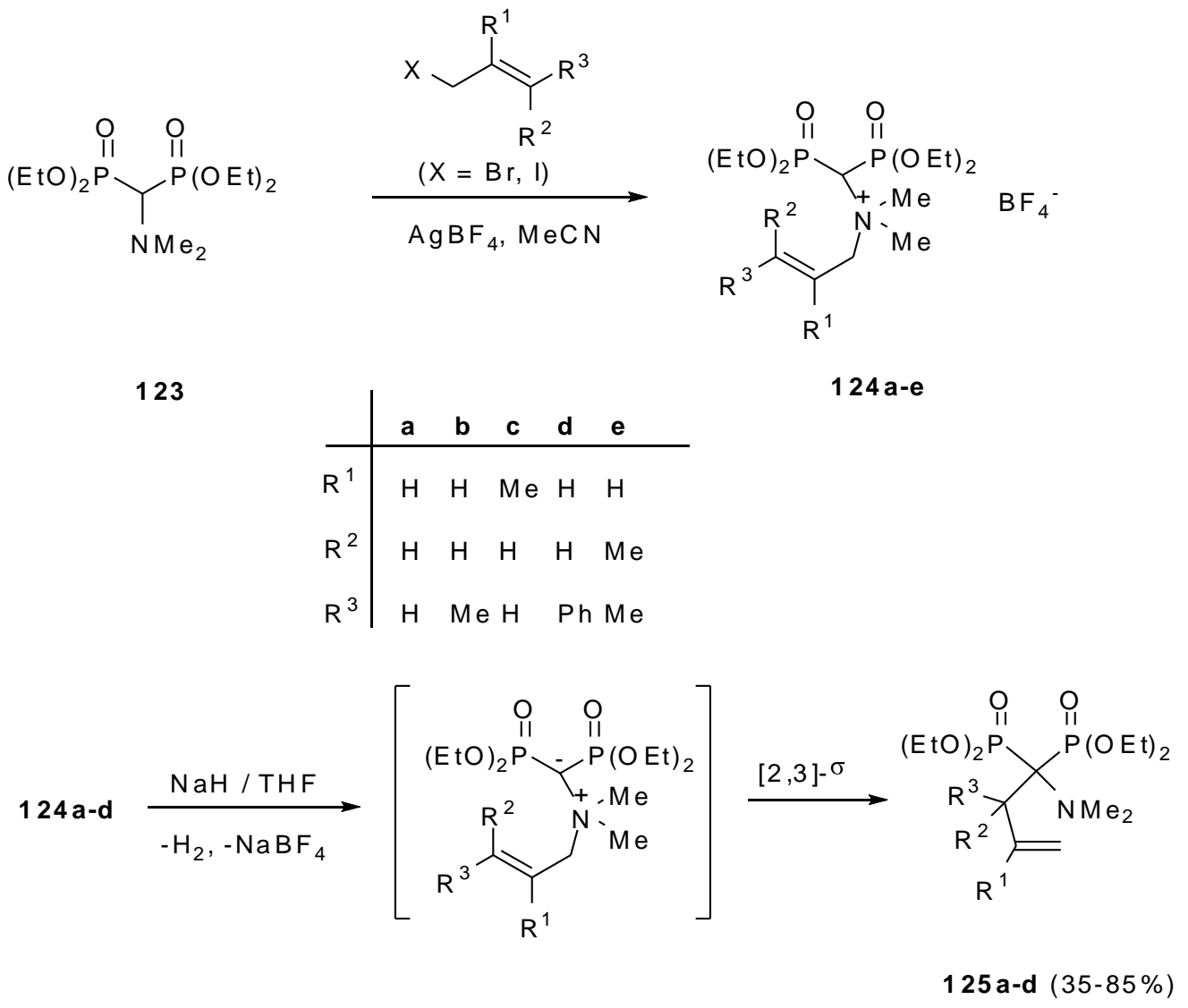

\section{Scheme 43}

The use of 1,1-bisphosphono-2-aza-1,3-dienes $\mathbf{1 2 6}$ for the synthesis of $N$-vinyl 2,2bisphosphonoaziridines 127 has been described by Stevens and co-workers. ${ }^{121}$ Treatment of the azadienes 126 with an excess of diazomethane in ether at room temperature yielded bisphosphonoaziridines 127 in 63-79\% yields. As a side reaction, the formation of phosphonates 128 was also observed (Scheme 44). 


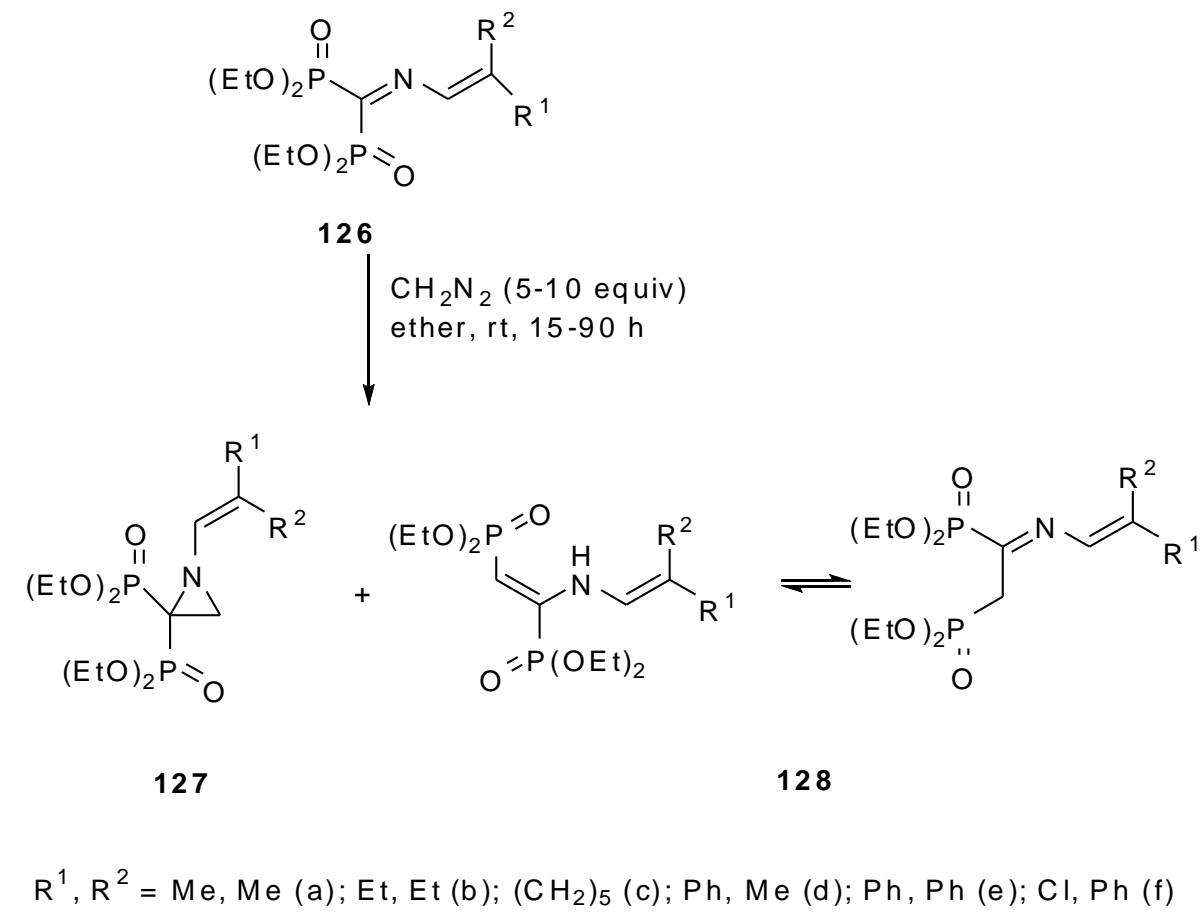

\section{Scheme 44}

\section{Miscellaneous methods}

It is also instructive to point out that the synthesis of dialkyl 1-aminomethylene-1,1bisphosphonates can be achieved by direct electrophilic amination of the corresponding methelenebisphosphonate esters. An example is the formation of the diallyl ester $\mathbf{1 2 9}$ as shown in Scheme $45 .{ }^{122}$

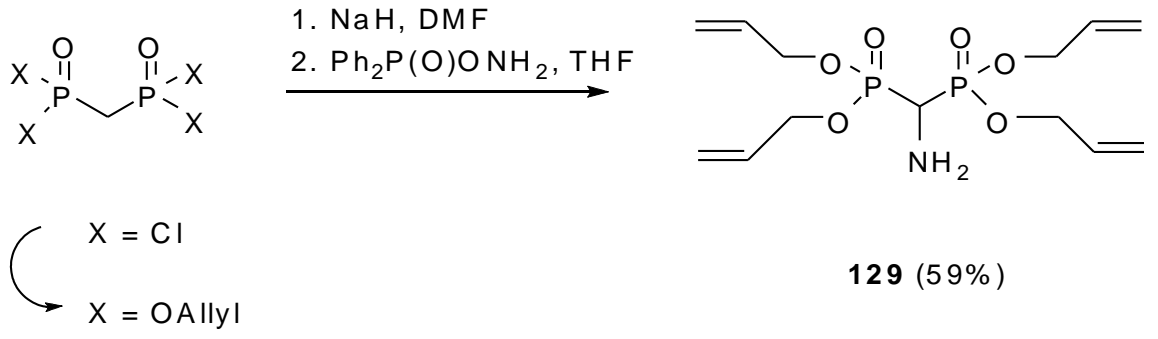

\section{Scheme 45}

A useful method providing a direct entry to the anchoring of $\mathrm{CH}\left(\mathrm{PO}_{3} \mathrm{R}_{2}\right)_{2}$ moiety onto aromatic amines has been developed by Taran and co-workers. ${ }^{35}$ The method uses a bisphosphonate-metal-carbenoid N-H insertion reaction for which $\mathrm{Rh}_{2}\left(\mathrm{NHCOCF}_{3}\right)_{4}$ was found to 
be an efficient catalyst. In general, the rhodium-catalyzed $\mathrm{N}-\mathrm{H}$ insertion reaction of diazo compound 130 worked successfully with aromatic amines containing both electron-donating and electron-withdrawing substituents affording the desired aminobisphosphonates $\mathbf{1 3 1}$ in good yields. Moreover, the procedure is suitable for the construction of dipodal bisphosphonate ligands such as $\mathbf{1 3 2}$ by using diamines as starting materials (Scheme 46). However, attempts to apply this method on aliphatic amines failed.
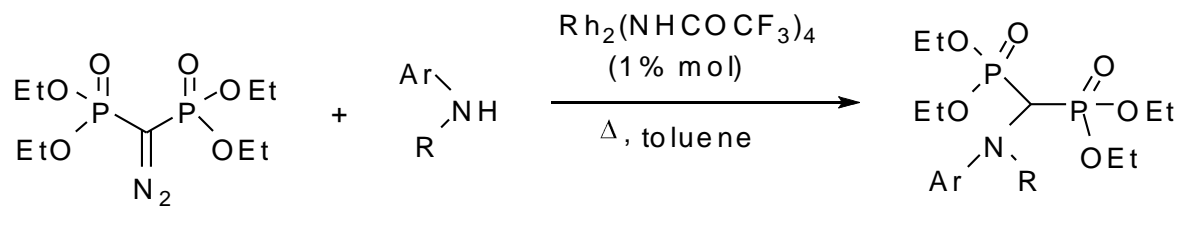

130

131 a-e $(66-87 \%)$

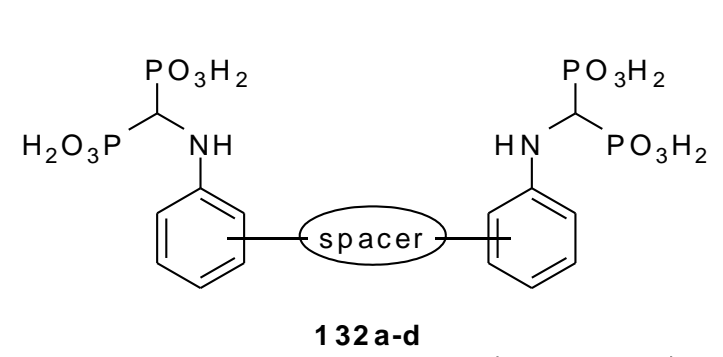

$\mathrm{a}: \mathrm{Ar}=\mathrm{Ph}, \mathrm{R}=\mathrm{H}$

$\mathrm{b}: \mathrm{Ar}=4-\mathrm{MeOC}_{6} \mathrm{H}_{4}, \mathrm{R}=\mathrm{H}$

$\mathrm{c}: \mathrm{Ar}=4-\mathrm{PhC}_{6} \mathrm{H} 4, \mathrm{R}=\mathrm{H}$

$\mathrm{d}: \mathrm{Ar}=4-\mathrm{O}_{2} \mathrm{NC}_{6} \mathrm{H}_{4}, \mathrm{R}=\mathrm{H}$

$\mathrm{e}: \mathrm{Ar}=\mathrm{Ph}, \mathrm{R}=\mathrm{Me}$

spacer $=-\mathrm{O}-(\mathrm{a}),-\left(\mathrm{CH}_{2}\right)_{2^{-}}(\mathrm{b})$<smiles>COc1cccc(Oc2ncco2)c1</smiles><smiles>CC(C)(C)c1cccc(C(C)(C)C)c1</smiles>

(d)

\section{Scheme 46}

Although much more limited in scope, metal-mediated insertion of isocyanides to $\mathrm{P}(\mathrm{O})-\mathrm{H}$ bond open a potentially useful route to bisphosphonate-like compounds. For example, the reaction of $\mathrm{Ph}_{2} \mathrm{P}(\mathrm{O}) \mathrm{H}$ with 2,6-dimethylphenylisocyanide in the presence of a catalytic amount of $\mathrm{Pd}_{2}(\mathrm{dba})_{3}(5 \mathrm{~mol} \%)$ in toluene predominantly produced the $1: 1$ adduct 133 . However, when the catalyst $\mathrm{Pd}_{2}(\mathrm{dba})_{3}$ was replaced with $\mathrm{Ph}\left(\mathrm{PPh}_{3}\right)_{3} \mathrm{Cl}$, compound 135a was formed in $95 \%$ yield. Under similar conditions, other rhodium(I), but not rhodium(III) complexes, also produce compounds 135a-d selectively (Scheme 47). Alkylphosphine oxides, such as $n$ - $\mathrm{Bu} 2 \mathrm{P}(\mathrm{O}) \mathrm{H}$ only gave a trace amount of bisphosphorylated compounds. ${ }^{123}$ 


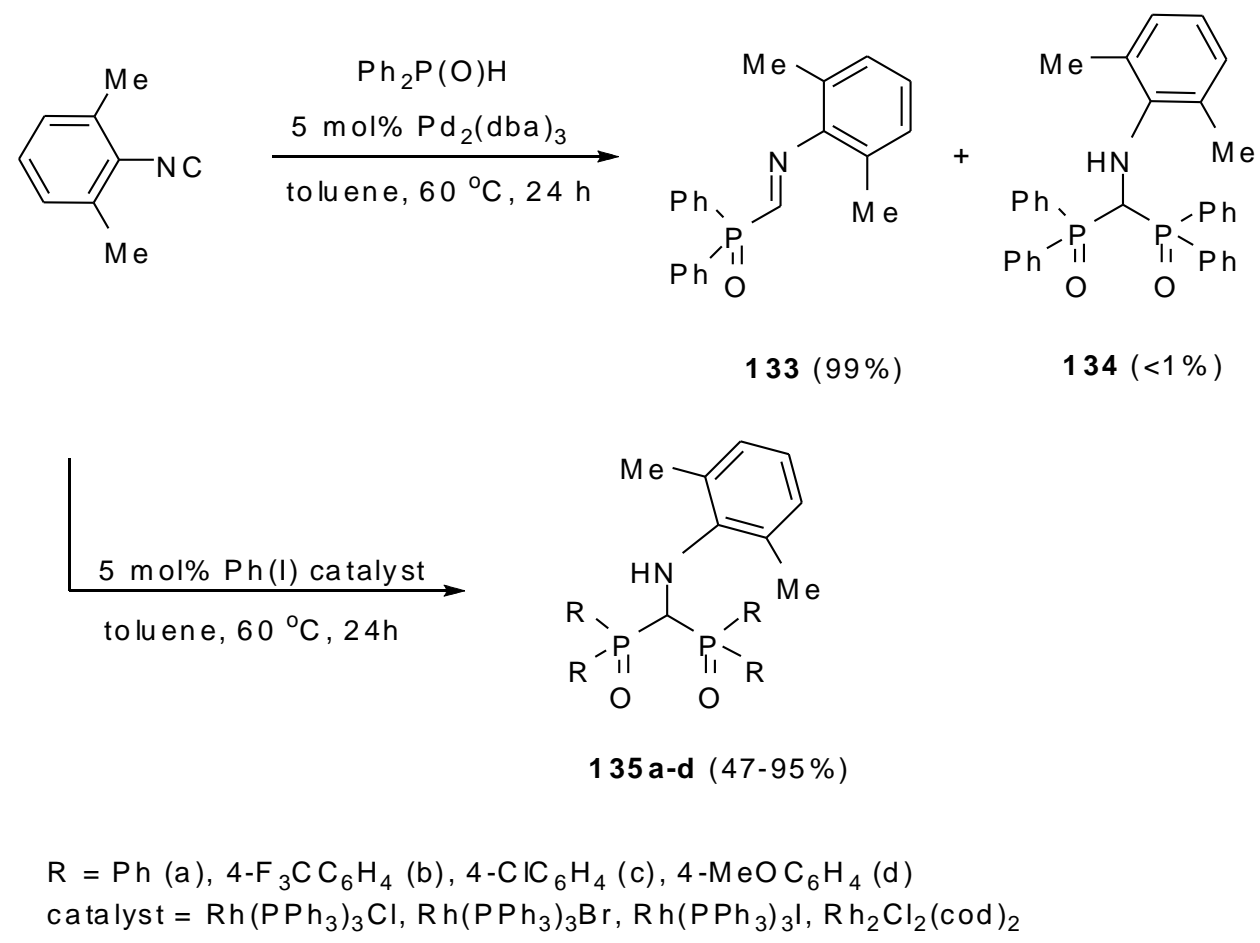

\section{Scheme 47}

\section{Conclusions}

It is evident from this account that 1-amino-1,1-bisphosphonates play an important role in organophosphorus chemistry and biochemistry. The last two decades have seen their increasing use in synthetic transformations directed towards the design of new drugs and biomedicals. Major advances have been made in the synthesis of $N$-heteryl-substituted bisphosphonates and the use of tetraethyl 1-aminomethylene-1,1-bisphosphonate in coupling reactions for the preparation of aminobisphosphonate conjugates. A major future goal remains to be the synthesis of a large diversity of functionalized, enantiomerically enriched aminobisphosphonates and bisphosphonate-containing amino acid mimetics. In our opinion, aminobisphosphonate-like pentacoordinated structures, which are directly mimics of transition state of phosphate hydrolysis, may be also very useful for biosciences.

\section{Acknowledgements}

We thank the Science and Technology Center in Ukraine (Project 5215) for financial support. 


\section{References}

1. Aminophosphonic and Aminophosphinic Acids; Kukhar, V. P.; Hudson, H. R., Eds.; Wiley: Chichester, 2000; 634 p.

2. Engelmann, M.; Pikl, J. US Patent 2304156, 1942.

3. Pikl, J. US Patent 2328358, 1943.

4. Learch, I.; Kottler, A. Ger. Pat. 1002355, 1957.

5. Zhang, S.; Gangal, G.; Uludağ, H. Chem. Soc. Rev. 2007, 36, 507.

6. Widler, L.; Jaeggi, K. A.; Glatt, M.; Müller, K.; Bachmann, R.; Bisping, M.; Born, A.-R.; Cortesi, R.; Guiglia, G.; Jeker, H.; Klein, R.; Ramseier, U.; Schmid, J.; Schreiber, G.; Seltenmeyer, Y.; Green, J. R. J. Med. Chem. 2002, 45, 3721.

7. Russell, R. G. G. Phosphorus, Sulfur Silicon Relat. Elem. 1999, 144, 793.

8. Russell, R. G. G.; Croucher, P. I.; Rogers, M. J. Osteoporos Int. 1999, Suppl. 2, 66.

9. Kotsikorou, E.; Song, Y.; Chan, J. M. W.; Faelens, S.; Tovian, Z.; Broderick, E.; Bakalara, N.; Docampo, R.; Oldfield, E. J. Med. Chem. 2005, 48, 6128.

10. Szajnman, S. H.; Ravaschino, E. L.; Docampo, R.; Rodriguez, J. B. Bioorg. Med. Chem. Lett. 2005, 15, 4685 .

11. Ghosh, S.; Chan, J. M. W.; Lea, C. R.; Meints, G. A.; Lewis, J. C.; Tovian, Z. S.; Flessner, R. M.; Loftus, T. C.; Bruchhaus, I.; Kendrick, H.; Croft, S. L.; Kemp, R. G.; Kobayashi, S.; Nozaki, T.; Oldfield, E. J. Med.Chem. 2004, 47, 175.

12. Sanders, J. M.; Gómez, A. O.; Mao, J.; Meints, G. A.; Van Brussel, E. M.; Burzynska, A.; Kafarski, P.; González-Pacanowska, D.; Oldfield, E. J. Med. Chem. 2003, 46, 5171.

13. Martin, M. B.; Sanders, J. M.; Kendrick, H.; de Luca-Fradley, K.; Lewis, J. C.; Grimley, J. S.; Van Brussel, E. M.; Olsen, J. R.; Meints, G. A.; Burzynska, A.; Kafarski, P.; Croft, S. L.; Oldfield, E. J. Med. Chem. 2002, 45, 2904.

14. Martin, M. B.; Grimley, J. S.; Lewis, J. C.; Heath, H. T.; Bailey, B. N.; Kendrick, H.; Yardley, V.; Caldera, A.; Lira, R.; Urbina, J. A.; Moreno, S. N.; Docampo, R.; Croft, S. L.; Oldfield, E. J. Med. Chem. 2001, 44, 909.

15. Rodriguez, N.; Bailey, B. N.; Martin, M. B.; Oldfield, E.; Urbina, J. A.; Docampo, R. J. Infect. Dis. 2002, 186, 138.

16. Leon, A.; Liu, L.; Yang, Y.; Hudock, M. P.; Hall, P. ;Yin, F. ;Studer, D.; Puan, K.-J.; Morita, C. T.; Oldfield, E. J. Med. Chem. 2006, 49, 7331.

17. Wang, L.; Kamath, A.; Das, H.; Li, L.; Bukowski, J. F. J. Clin. Inv. 2001, 108, 1349.

18. Kafarski, P.; Lejczak, B.; Forlani, G.; Chuiko, A.; Lozinsky, M.; Jasicka-Misiak, I.; Czekała, K.; Lipok, J. Phosphorus, Sulfur Silicon Relat. Elem. 1999, 144, 621.

19. Kafarski, P.; Lejczak, B.; Forlani, G. Heteroatom Chem. 2000, 11, 449.

20. Mao, J.; Mukherjee, S.; Zhang, Y.; Cao, R.; Sanders, J. M.; Song, Y.; Zhang, Y.; Meints, G. A.; Gao, Y. G.; Mukkamala, D.; Hudock, M. P.; Oldfield, E. J. Am. Chem. Soc. 2006, 128, 14485.

21. Szabo, C. M.; Martin, M. B.; Oldfield, E. J. Med. Chem. 2002, 45, 2894. 
22. Martin, M. B.; Arnold, W.; Heath III, H. T.; Urbina, J. A.; Oldfield, E. Biochem. Biophys. Res. Comm. 1999, 263, 754.

23. Sietsema, W. K.; Ebetino, F. H.; Salvagno, A. M.; Bevan, J. A. Drugs Exptl. Clin. Res. 1989, $15,389$.

24. Forlani, G.; Giberti, S.; Berlicki, Ł.; Petrollino, D.; Kafarski, P. J. Agr. Food Chem. 2007, 55, 4340.

25. Yajima, S.; Hara, K.; Sanders, J. M.; Yin, F.; Ohsawa, K.; Wiesner, J.; Jomaa, H.; Oldfield, E. J. Am. Chem. Soc. 2004, 126, 10824.

26. Hudock, M. P. Sanz-Rodríguez, C. E. Song, Y. Chan, J. M. W. Zhang, Y. Odeh, S. Kosztowski, T. Leon-Rossell, A. Concepción, J. L. Yardley, V. Croft, S. L. Urbina, J. A.; Oldfield, E. J. Med. Chem. 2006, 49, 215.

27. Reszka, A. A; Rodan, G. A. Mini Rev. Med. Chem. 2004, 4, 711.

28. Uludag, H. Curr. Pharm. Design 2002, 8, 1929.

29. Takeuchi, M. Chem. Pharm. Bull. 1993, 41, 688.

30. Hiraga, T.; Tanaka, S.; Yamamoto, M.; Nakagima, T.; Ozawa, H. Bone 1996, 18, 1.

31. Rogers, M. J.; Xiong, X. J.; Brown, R. J.; Watts, D. J.; Russell, R. G. G.; Bayless, A. V.; Ebetino, F. H. Mol. Pharmacol. 1995, 47, 398.

32. Roth, A. G.; Drescher, D.; Yang, Y.; Redmer, S.; Uhlig, S.; Arenz, C. Angew. Chem. Int. Ed. Engl. 2009, 48, 7560.

33. Yokomatsu, T.; Yoshida, Y.; Nakabayashi, N.; Shibuya, S. J. Org . Chem. 1994, 59, 7562.

34. Kubíček, V.; Rudovský, J.; Kotek, J.; Hermann, P.; Elst, V. L.; Muller, R. N.; Kolar, Z. I.; Wolterbeek, H. T.; Peters, J. A.; Lukeš, I. J. Am. Chem. Soc. 2005, 127, 16477.

35. Lecerclé, D.; Gabillet, S.; Gomis, J.-M.; Taran, F. Tetrahedron Lett. 2008, 49, 2083.

36. Olive, G.; Jacques, A. Phosphorus, Sulfur Silicon Relat. Elem. 2003, 178, 33.

37. Olive, G.; Le Moigne, F.; Mercier, A.; Tordo, P. Synth. Commun. 2000, 30, 619.

38. Olive, G.; Rockenbauer, A.; Rozanska, X.; Jacques, A.; Peeters, D.; German, A. Phosphorus, Sulfur Silicon Relat. Elem. 2007, 182, 2359.

39. Olive, G.; Le Moigne, F.; Mercier, A.; Rockenbauer, A.; Tordo, P. J. Org . Chem. 1998, 63, 9095.

40. Matczak-Jon, E.; Kowalik-Jankowska, T.; Slepokura, K.; Kafarski, P.; Rajewska, A. J. Chem. Soc. Dalton Trans. 2010, 39, 1207.

41. Młynarz, P.; Jewginski, M.; Śliwińska, S.; Latajka, R.; Schroeder, G.; Kafarski, P. Heteroatom Chem. 2007, 18, 774.

42. Fleisch, H. Bisphosphonates in Bone Disease. From the Laboratory to the Patient; 4th ed. London: Academic Press, 2000; 212 p.

43. Breuer, E. The Development of Bisphosphonates as Drugs. In Analogue-based Drug Discovery; Wiley-VCH: Weinheim, 2006; pp. 371-384.

44. Matkovskaya, T. A.; Popov, K. I.; Yurieva, E. A. Bisphosphonates. Properties, structure and application in medicine; Khimiya: Moskow, 2001; 224 p. (in russian).

45. Drake, M. T.; Clarke, B. L.; Khosla, S. Mayo Clin. Proc. 2008, 83, 1032. 
46. Fleisch, H. Breast Cancer Res. 2002, 4, 30.

47. Lejczak, B.; Kafarski, P. Top. Heterocycl. Chem. 2009, 20, 31.

48. Karamustafa, F.; Gelebi, N. FABAD J. Pharm. Sci. 2006, 31, 31.

49. Russell, R. G. G.; Rogers, M. J. Bone 1999, 25, 97.

50. Abdou, W. M.; Shaddy, A. A. Arkivoc 2009, (ix), 143.

51. Curry, J. D.; Nicholson, D. A.; Quimby, O. T. Top. Phosph. Chem. 1972, 7, 37.

52. Czekanski, T.; Witek, S.; Gross, H.; Costizella, B. Wiad. Chem. 1987, 41, 801.

53. Lecouvey, M.; Leroux, Y. Heteroatom Chem. 2000, 11, 556.

54. Matczak-Jon, E.; Videnova-Adrabinska, V. Coord. Chem. Rev. 2005, 249, 2458.

55. Zolotuchina, M. M.; Krutikov, V. I.; Lavrentiev, A. N. Russ. Chem. Rev. (Engl. Transl.) 1993, 62, 647.

56. Romanenko, V. D.; Kukhar, V. P. Chem. Rev. 2006, 106, 3868.

57. Plöger, W.; Schindler, N.; Wollmann, K.; Worms, K. H. Z. Anorg. Allg. Chem. 1972, 389, 119.

58. Rusina, M. N.; Balashova, T. M.; Zhadanov, B. V.; Tsitrina, A. Y.; Polyakova, I. A. Zh. Obshch. Khim. 1977, 47, 1721.

59. Alferiev, I. S.; Bobkov, S. Y.; Kotlyarevskii, I. L. Izv. Akad. Nauk SSSR [Khim] 1987, 865.

60. Fukuda, M.; Okamoto, Y.; Sakurai, H. Bull. Chem. Soc. Jpn. 1975, 48, 1030.

61. Wu, M.; Chen, R.; Huang, Y. Synth. Commun. 2004, 34, 1393.

62. Alferiev, I. S.; Bobkov, S. Y. Z. Naturforsh. 1992, 47b, 1213.

63. Griffiths, D. V.; Hughes, J. M.; Brown, J. W.; Caesar, J. C.; Swetnam, S. P.; Cumming, S. A.; Kelly, J. D. Tetrahedron 1997, 53, 17815.

64. Worms, K.-H.; Blum, H. Liebigs Ann. Chem. 1982, 275.

65. Gross, H.; Costisella, B.; Gnauk, T.; Brennecke, L. J. Prakt. Chem. 1976, 318, 116.

66. Degenhardt, C. Synth. Commun. 1982, 12, 415.

67. Qian, D. Q.; Shi, X. D.; Zeng, X. Z.; Cao, R. Z.; Liu, L. Z. Tetrahedron Lett. 1997, 38, 6245.

68. Qian, D. Q.; Shi, X. D. Cao, R. Z.; Liu, L. Z. Heteroatom Chem. 1999, 10, 271.

69. Wang, W. H.; Xu, G. Y.; Cao, R. Z.; Liu, L. Z. Heteroatom Chem. 2000, 11, 512.

70. Qian, D.; Zeng, X.; Shi, X.; Cao, R.; Liu, L. Heteroatom Chem. 1997, 8, 517.

71. Olive, G.; van Genderen, M. H. P. Magn. Res. Chem. 2000, 38, 379.

72. Balashova, T. M.; Kolpakova, I. D. Methods of obtaining of chemical reagents and preparations 1973, 25, 11-14, 18-19 (in russian).

73. Serebrennikova, G. A.; Koltsova, G. N.; Chupin, V. V.; Chuvilin, A. N.; Rozenberg, G. Ya.; Evstegneeva, R. P. J. Gen. Chem. USSR (Engl. Transl.) 1985, 55, 390.

74. Dudko, A. V.; Bon V. V.; Kozachkova, A. N.; Tsarik, N. V.; Pehnio, V. I. Ukr. Khim. Zh. 2008, 74, 104.

75. Kaabak, L. V.; Kuzmina, N. E.; Khudenko, A. V.; Tomilov, A. P. Russ. J. Gen. Chem. 2006, $76,1673$.

76. Orlovskii, V. V.; Vovsi, B. A. J. Gen. Chem. USSR (Engl. Transl.) 1976, 46, 294. 
77. Bandurina, T. A; Konyukhov, V. N.; Ponomareva, O. A; Barybin, A. S.; Pushkareva, Z. V. Pharm. Chem. J. 1978, 12, 1428.

78. Grigorovich, M. M.; Zhadanov, B. N.; Polyakova, I. A.; Yudina, E. A.; Kalinichenko, I. I.; Rykov, S. V. J. Gen. Chem. USSR (Engl. Transl.) 1984, 54, 898.

79. Matevosyan, G. L.; Matyushichev, I. Y.; Zavlin, P. M. J. Gen. Chem. USSR (Engl. Transl.) 1987, 57, 939.

80. Blum, H. Z. Naturforsh. 1988, 43b, 75.

81. Suzuki, F.; Fujikawa, Y.; Yamamoto, S.; Mizutani, H.; Funabashi, C.; Ohya, T.; Ikai, T.; Oguchi, T. DE 2831578 A1, 1978. Chem. Abstr. 1979, 90, 187121.

82. Maier, L. Phosphorus, Sulfur Silicon Relat. Elem. 1981, 11, 311.

83. Ebetino, F. H.; Jamieson, L. A. Phosphorus, Sulfur Silicon Relat. Elem. 1990, 51, 23.

84. Soloducho, J.; Gancarz, R.; Wieczorek, P.; Korf, J.; Hafner, J.; Lejczak, B.; Kafarski, P. Patent PL 172268 B1, 1997. Chem. Abstr. 1998, 128, 61631.

85. Mimura, M.; Hayashida, M.; Nomiyama, K.; Ikegami, S.; Iida, Y.; Tamura, M.; Hiyama, Y.; Ohishi, Y. Chem. Pharm. Bull. 1993, 41, 1971.

86. Matczak-Jon, E.; Videnova-Adrabińska, V.; Burzyńska, A.; Kafarski, P.; Lis, T. Chemistry 2005, 11, 2357.

87. Kafarski, P.; Lejczak, B.; Forlani, G.; Gancarz, R.; Torreilles, C.; Grembecka, J.; Ryczek, A.; Wieczorek, P. J. Plant Growth Regul. 1997, 16, 153.

88. Minaeva, L. I.; Patrikeeva, L. S.; Kabachnik, M. M.; Beletskaya, I. P.; Orlinson, B. S.; Novakov, I. A. Heteroatom Chem. 2011, 22, 55.

89. Krutikov, V. I.; Erkin, A. V.; Pautov, P. A.; Zolotukhina, M. M. Russ. J. Gen. Chem. 2003, $73,187$.

90. Kaboudin, B.; Alipour, S. Tetrahedron Lett. 2009, 50, 4243.

91. Dąbrowska, E.; Burzyńska, A.; Mucha, A.; Matczak-Jon, E.; Sawka-Dobrowolska, W.; Berlicki, Ł.; Kafarski, P. J. Organomet. Chem. 2009, 694, 3806.

92. Árstad, E.; Hoff, P.; Skattebøl, L.; Skretting, A.; Breistøl, K. J. Med. Chem. 2003, 46, 3021.

93. De Schutter, J. W.; Zaretsky, S.; Welbourn, S.; Pause, A.; Tsantrizos, Y. S. Bioorg. Med. Chem. Lett. 2010, 20, 5781.

94. Kantoci, D.; Denike, J. K.; Wechter, W. J. Synth. Commun. 1996, 26, 2037.

95. Jiang, Q.; Yang, L.; Hai, L.; Wu, Y. Lett. Org. Synth. 2008, 86, 229.

96. Prishchenko, A. A.; Livantsov, M. V.; Novikova, O. P.; Livantsova, L. I. Russ. J. Gen. Chem. 2009, 79, 1936.

97. McNulty, J.; Das, P. Tetrahedron 2009, 65, 7794.

98. Masschelein, K. G. R.; Stevens, C. V. J. Org . Chem. 2007, 72, 9248.

99. Rassukana, Y. V.; Davydova, K. O.; Onysko, P. P.; Sinitsa, A. D. J. Fluorine Chem. 2002, 117, 107.

100.Rassukana, Y. V.; Onysko, P. P.; Grechukha, A. G.; Sinitsa, A. D. Eur. J. Org. Chem. 2003, 2003, 4181.

101.Wu, M.; Chen, R.; Huang, Y. Synthesis 2004, 2441. 
102.Sturtz, G.; Couthon, H.; Fabulet, O.; Mian, M.; Rosini, S. Eur. J. Med. Chem. 1993, $28,899$.

103. Morioka, M.; Kamizono, A.; Takikawa, H.; Mori, A.; Ueno, H.; Kadowaki, S.-i.; Nakao, Y.; Kato, K.; Umezawa, K. Bioorg. Med. Chem. 2010, 18, 1143.

104.Reddy, R.; Dietrich, E.; Lafontaine, Y.; Houghton, T. J.; Belanger, O.; Dubois, A.; Arhin, F. F.; Sarmiento, I.; Fadhil, I.; Laquerre, K.; Ostiguy, V.; Lehoux, D.; Moeck, G.; Parr, T. R.; Far, A. R. ChemMedChem 2008, 3, 1863.

105.Bailly, T.; Burgada, R.; Prangé, T.; Lecouvey, M. Tetrahedron Lett. 2003, 44, 189.

106.El-Mabhouh, A.; Angelov, C.; McEwan, A.; Jia, G.; Mercer, J. Cancer Biother. Radiopharm. 2004, 19, 627.

107.Xu, G.; Yang, C.; Liu, B.; Wu, X.; Xie, Y. Heteroatom Chem. 2004, 15, 251.

108. Chuiko, A. L.; Filonenko, L. P.; Borisevich, A. N.; Lozinskii, M. O. Zh. Org. Khim. 1995, 65, 1332.

109.Chuiko, A. L.; Lozinsky, M. O.; Jasicka-Misiak, I.; Kafarski, P. J. Plant Growth Regul. 1999, $18,171$.

110. Vovk, A. I.; Chuiko, A. L.; Kononets, L. A.; Tanchuk, V. Y.; Murav'eva, I. V.; Lozinsky, M.; O.; Kukhar, V. P. Russ. J. Bioorg. Chem. 2008, 34, 60.

111.Chuiko, A. L.; Filonenko, L. P.; Borisevich, A. N.; Lozinskii, M. O. Russ. J. Gen. Chem. 2009, 79, 72.

112. Chuiko, A. L.; Filonenko, L. P.; Lozinskii, M. O. Russ. J. Gen. Chem. 2009, 79, 57.

113. Chuiko, A. L.; Borisenko, A. N.; Lozinskii, M. O. Russ. J. Gen. Chem. 2009, 79, 67.

114.Lozinsky, M.; Chuiko, A.; Kafarski, P.; Jasicka-Misiak, I.; Filonenko, L.; Borisevich, A. Phosphorus, Sulfur Silicon Relat. Elem. 1999, 147, 241.

115.El-Mabhouh, A. A; Angelov, C. A.; Cavell, R.; Mercer, J. R. Nucl. Med. Biol. 2006, 33, 715.

116.Palacios, F.; Gil, M. J.; de Marigorta, E. M.; Rodríguez, M. Tetrahedron 2000, 56, 6319.

117.Beck, J.; Gharbi, S.; Herteg-Fernea, A.; Vercheval, L.; Bebrone, C.; Lassaux, P.; Zervosen, A.; Marchand-Brynaert, J. Eur. J. Org. Chem. 2009, 85.

118.Shchmarov, A. A.; Krutikov, V. I.; Travkina, T. O.; Sivuhin, C. V. J. Gen. Chem. USSR 2000, 70, 521.

119.Shevchuk, M. V.; Sorochynsky, A. E; Khilya, V. P. Romanenko V. D.; Kukhar V. P. Synlett 2010, 73.

120.Lemee, L.; Gulea, M.; Saquet, M.; Masson, S.; Collignon, N. Heteroatom Chem. 1999, 10, 281.

121.Mortier, P. P. J.; Van Waes, F. E. A.; Masschelein, K. G. R.; Heugebaert, T. S. A.; Stevens, C. V. Tetrahedron Letters 2011, 52, 4273.

122. Tanaka, K. S. E.; Dietrich, E.; Ciblat, S.; Métayer, C.; Arhin, F. F.; Sarmiento, I.; Moeck, G.; Parr, T. R.; Far, A. R. Bioorg. Med. Chem. Lett. 2010, 20, 1355.

123.Hirai, T.; Han, L.-B. J. Am. Chem. Soc. 2006, 128, 7422. 